

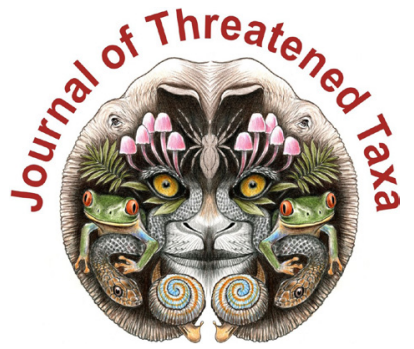

ISSN 0974-7907 (Online); ISSN $0974-7893$ (Print)

Publisher

Host

Wildlife Information Liaison Development Society

www.wild.zooreach.org

Zoo Outreach Organization www.zooreach.org

No. 12, Thiruvannamalai Nagar, Saravanampatti - Kalapatti Road, Saravanampatti, Coimbatore, Tamil Nadu 641035, India

Ph: +91 9385339863 | www.threatenedtaxa.org

Email: sanjay@threatenedtaxa.org

EDITORS

\section{Founder \& Chief Editor}

Dr. Sanjay Molur

Wildlife Information Liaison Development (WILD) Society \& Zoo Outreach Organization (ZOO),

12 Thiruvannamalai Nagar, Saravanampatti, Coimbatore, Tamil Nadu 641035, India

\section{Deputy Chief Editor}

Dr. Neelesh Dahanukar

Noida, Uttar Pradesh, India

\section{Managing Editor}

Mr. B. Ravichandran, WILD/ZOO, Coimbatore, India

\section{Associate Editors}

Dr. Mandar Paingankar, Government Science College Gadchiroli, Maharashtra 442605, India

Dr. Ulrike Streicher, Wildlife Veterinarian, Eugene, Oregon, USA

Ms. Priyanka Iyer, ZOO/WILD, Coimbatore, Tamil Nadu 641035, India

Dr. B.A. Daniel, ZOO/WILD, Coimbatore, Tamil Nadu 641035, India

\section{Editorial Board}

Dr. Russel Mittermeier

Executive Vice Chair, Conservation International, Arlington, Virginia 22202, USA

\section{Prof. Mewa Singh Ph.D., FASc, FNA, FNASc, FNAPsy}

Ramanna Fellow and Life-Long Distinguished Professor, Biopsychology Laboratory, and Institute of Excellence, University of Mysore, Mysuru, Karnataka 570006, India; Honorary Professor, Jawaharlal Nehru Centre for Advanced Scientific Research, Bangalore; and Adjunct Professor, National Institute of Advanced Studies, Bangalore

\section{Stephen D. Nash}

Scientific Illustrator, Conservation International, Dept. of Anatomical Sciences, Health Sciences Center, T-8, Room 045, Stony Brook University, Stony Brook, NY 11794-8081, USA

\section{Dr. Fred Pluthero}

Toronto, Canada

\section{Dr. Priya Davidar}

Sigur Nature Trust, Chadapatti, Mavinhalla PO, Nilgiris, Tamil Nadu 643223, India

\section{Dr. Martin Fisher}

Senior Associate Professor, Battcock Centre for Experimental Astrophysics, Cavendish

Laboratory, JJ Thomson Avenue, Cambridge CB3 OHE, UK

\section{Dr. John Fellowes}

Honorary Assistant Professor, The Kadoorie Institute, 8/F, T.T. Tsui Building, The University of Hong Kong, Pokfulam Road, Hong Kong

\section{Prof. Dr. Mirco Solé}

Universidade Estadual de Santa Cruz, Departamento de Ciências Biológicas, Vice-coordenado do Programa de Pós-Graduação em Zoologia, Rodovia Ilhéus/Itabuna, Km 16 (45662-000)

Salobrinho, Ilhéus - Bahia - Brasil

\section{Dr. Rajeev Raghavan}

Professor of Taxonomy, Kerala University of Fisheries \& Ocean Studies, Kochi, Kerala, India

\section{English Editors}

Mrs. Mira Bhojwani, Pune, India

Dr. Fred Pluthero, Toronto, Canad

Mr. P. Ilangovan, Chennai, India

Web Development

Mrs. Latha G. Ravikumar, ZOO/WILD, Coimbatore, India

\section{Typesetting}

Mr. Arul Jagadish, ZOO, Coimbatore, India

Mrs. Radhika, ZOO, Coimbatore, India

Mrs. Geetha, ZOO, Coimbatore India
Fundraising/Communications

Mrs. Payal B. Molur, Coimbatore, India

Subject Editors 2018-2020

Fungi

Dr. B. Shivaraju, Bengaluru, Karnataka, India

Dr. R.K. Verma, Tropical Forest Research Institute, Jabalpur, India

Dr. Vatsavaya S. Raju, Kakatiay University, Warangal, Andhra Pradesh, India

Dr. M. Krishnappa, Jnana Sahyadri, Kuvempu University, Shimoga, Karnataka, India

Dr. K.R. Sridhar, Mangalore University, Mangalagangotri, Mangalore, Karnataka, India

Dr. Gunjan Biswas, Vidyasagar University, Midnapore, West Bengal, India

\section{Plants}

Dr. G.P. Sinha, Botanical Survey of India, Allahabad, India

Dr. N.P. Balakrishnan, Ret. Joint Director, BSI, Coimbatore, India

Dr. Shonil Bhagwat, Open University and University of Oxford, UK

Prof. D.J. Bhat, Retd. Professor, Goa University, Goa, India

Dr. Ferdinando Boero, Università del Salento, Lecce, Italy

Dr. Dale R. Calder, Royal Ontaro Museum, Toronto, Ontario, Canada

Dr. Cleofas Cervancia, Univ. of Philippines Los Baños College Laguna, Philippines

Dr. F.B. Vincent Florens, University of Mauritius, Mauritius

Dr. Merlin Franco, Curtin University, Malaysia

Dr. V. Irudayaraj, St. Xavier's College, Palayamkottai, Tamil Nadu, India

Dr. B.S. Kholia, Botanical Survey of India, Gangtok, Sikkim, India

Dr. Pankaj Kumar, Kadoorie Farm and Botanic Garden Corporation, Hong Kong S.A.R., China

Dr. V. Sampath Kumar, Botanical Survey of India, Howrah, West Bengal, India

Dr. A.J. Solomon Raju, Andhra University, Visakhapatnam, India

Dr. Vijayasankar Raman, University of Mississippi, USA

Dr. B. Ravi Prasad Rao, Sri Krishnadevaraya University, Anantpur, India

Dr. K. Ravikumar, FRLHT, Bengaluru, Karnataka, India

Dr. Aparna Watve, Pune, Maharashtra, India

Dr. Qiang Liu, Xishuangbanna Tropical Botanical Garden, Yunnan, China

Dr. Noor Azhar Mohamed Shazili, Universiti Malaysia Terengganu, Kuala Terengganu, Malaysia

Dr. M.K. Vasudeva Rao, Shiv Ranjani Housing Society, Pune, Maharashtra, India

Prof. A.J. Solomon Raju, Andhra University, Visakhapatnam, India

Dr. Mandar Datar, Agharkar Research Institute, Pune, Maharashtra, India

Dr. M.K. Janarthanam, Goa University, Goa, India

Dr. K. Karthigeyan, Botanical Survey of India, India

Dr. Errol Vela, University of Montpellier, Montpellier, France

Dr. P. Lakshminarasimhan, Botanical Survey of India, Howrah, India

Dr. Larry R. Noblick, Montgomery Botanical Center, Miami, USA

Dr. K. Haridasan, Pallavur, Palakkad District, Kerala, India

Dr. Analinda Manila-Fajard, University of the Philippines Los Banos, Laguna, Philippines

Dr. P.A. Sinu, Central University of Kerala, Kasaragod, Kerala, India

Dr. Afroz Alam, Banasthali Vidyapith (accredited A grade by NAAC), Rajasthan, India

Dr. K.P. Rajesh, Zamorin's Guruvayurappan College, GA College PO, Kozhikode, Kerala, India

Dr. David E. Boufford, Harvard University Herbaria, Cambridge, MA 02138-2020, USA

Dr. Ritesh Kumar Choudhary, Agharkar Research Institute, Pune, Maharashtra, India

Dr. Navendu Page, Wildlife Institute of India, Chandrabani, Dehradun, Uttarakhand, India

\section{Invertebrates}

Dr. R.K. Avasthi, Rohtak University, Haryana, India

Dr. D.B. Bastawade, Maharashtra, India

Dr. Partha Pratim Bhattacharjee, Tripura University, Suryamaninagar, India

Dr. Kailash Chandra, Zoological Survey of India, Jabalpur, Madhya Pradesh, India

Dr. Ansie Dippenaar-Schoeman, University of Pretoria, Queenswood, South Africa

Dr. Rory Dow, National Museum of natural History Naturalis, The Netherlands

Dr. Brian Fisher, California Academy of Sciences, USA

Dr. Richard Gallon, llandudno, North Wales, LL30 1UP

Dr. Hemant V. Ghate, Modern College, Pune, India

Dr. M. Monwar Hossain, Jahangirnagar University, Dhaka, Bangladesh

Mr. Jatishwor Singh Irungbam, Biology Centre CAS, Branišovská, Czech Republic.

Dr. Ian J. Kitching, Natural History Museum, Cromwell Road, UK

Dr. George Mathew, Kerala Forest Research Institute, Peechi, India

For Focus, Scope, Aims, and Policies, visit https://threatenedtaxa.org/index.php/JoTT/aims_scope
For Article Submission Guidelines, visit https://threatenedtaxa.org/index.php/JoTT/about/submissions
For Policies against Scientific Misconduct, visit https://threatenedtaxa.org/index.php/JoTT/policies_various

continued on the back inside cover 


\title{
Patterns of forest cover loss in the terrestrial Key Biodiversity Areas in the Philippines: critical habitat conservation priorities
}

\section{Bernard Peter O. Daipan (D)}

Department of Forest Biological Sciences, College of Forestry, Benguet State University, La Trinidad, Benguet 2601, Philippines. bp.daipan@bsu.edu.ph

\begin{abstract}
The Philippines, home to over 20,000 endemic species of plants and animals, is facing a biodiversity crisis due to the constant decrease of forest cover. The Key Biodiversity Area (KBA) approach was developed to conserve species threatened with extinction using a site-based conservation strategy to select globally important sites using threshold-based criteria for species irreplaceability and vulnerability. This study investigates the applicability of remotely sensed data through geospatial analysis to quantify forest cover loss of the 101 terrestrial KBAs in the country between 2001 and 2019. Results showed that the study sites had 4.5 million hectares (ha) of forest in the year 2000. However, these sites have lost about 270,000 ha of forest in nearly two decades, marking a steady decline with an annual deforestation rate of 14,213 ha per year in these terrestrial KBAs. The majority of the study sites (58) had a high percentage of forest loss $(>3.13 \%)$, and these should be prioritized for conservation. By the year 2030, it is forecast that a total of 331 thousand ha of forest will be lost unless there is a transformational change in the country's approach to dealing with deforestation. The results of this study provide relevant data and information in forest habitat in near real-time monitoring to assess the impact and effectiveness of forest governance and approaches within these critical habitats.
\end{abstract}

Keywords: Deforestation, forest habitat, geospatial technology, KBA.

Abbreviations: AZE-Alliance for Zero Extinction | DENR-Department of Environment and Natural Resources | GIS-Geographic Information System | IUCN-International Union for the Conservation of Nature | KBA-Key Biodiversity Area | UNEP-United Nations Environment Programme.

Citation: Daipan, B.P.O. (2021).Patterns of forest cover loss in the terrestrial Key Biodiversity Areas in the Philippines: critical habitat conservation priorities. Journal of Threatened Taxa 13(13): 20019-20032. https://doi.org/10.11609/jott.6904.13.13.20019-20032

Copyright: ( ) Daipan 2021. Creative Commons Attribution 4.0 International License. JoTT allows unrestricted use, reproduction, and distribution of this article in any medium by providing adequate credit to the author(s) and the source of publication.

Funding: None.

Competing interests: The authors declare no competing interests.

Author details: BERNARD PETER O. DAIPAN is currently the department chairperson of the Forest Biological Sciences (FBS) and research coordinator of the College of Forestry, Benguet State University in the Philippines. He previously worked with the Conservation and Development Division of the DENR-CAR for almost seven years before joining the academy. At present, the author is pursuing his PhD degree in Forestry Major in Forest Biological Sciences at the University of the Philippines Los Baños (UPLB).

Acknowledgements: The author would like to acknowledge the faculty and staff of the Department of Forest Biological Sciences, College of Forestry-Benguet State University (BSU) for the inclusion of this study in the College Research Agenda. Also, the author is very grateful for the DENR-Cordillera Region, Birdlife International, Global Forest Watch, and the QGIS team for the free accessible data and software. Finally, this study would not have been possible without the immeasurable support of Ms. Sarah Jane and Mr. Paul Isaac.

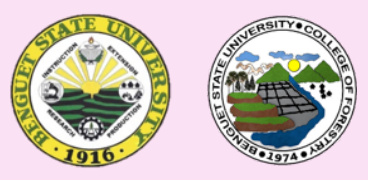




\section{INTRODUCTION}

Forests are home to over $80 \%$ of the earth's terrestrial biodiversity (Aerts \& Honnay 2011), including almost half of all avian species (Hilton-Taylor et al. 2009). Forests provide many ecosystem services that include conservation of threatened and endemic species (Gibson et al. 2011). However, these forests have undergone remarkable pressure (Drummond \& Loveland 2010) over the past decades, leading to a global biodiversity crisis (Driscoll et al. 2018) which is even worse than climate change (University of Copenhagen 2012). There is no doubt that habitat loss, caused by the conversion of forest to non-forest land uses such as agricultural and built-up areas, is the predominant threat to biodiversity (Foley et al. 2005; Estavillo et al. 2013). As a result, many endemic species have either become extinct or threatened with extinction (Brooks et al. 2002). In the Philippines, there are more than 20,000 endemic species of plants and animals (Mittermeier et al. 1998; Conservation International Philippines 2020) and the country is home to $20 \%$ of all known flora and fauna species (Ambal et al. 2012). This mega-diverse country has long been recognized as one of the top biodiversity hotspots in the world (Gaither \& Rocha 2013) due to the constant exploitation and destruction of its forest resources. This habitat destruction can generate zoonotic diseases (UNEP 2020), such as COVID-19 that caused a worldwide pandemic (Cucinotta \& Vanelli 2020). Biodiversity also protects humans against infectious disease (Wood et al. 2014; Levi et al. 2016)

To this end, the Key Biodiversity Area (KBA) approach was developed. This site-based conservation approach is considered one the most effective means to halt biodiversity loss on global and regional scales (Eken et al. 2004; UNEP-CBD 2010). The KBAs are promoted by the International Union for the Conservation of Nature (IUCN) to identify and delineate important sites for the global persistence of biodiversity as manageable units (IUCN 2016; Kulberg et al. 2019), using standard criteria based on the concepts of species irreplaceability and vulnerability (Langhammer et al. 2007; Melovski et al. 2012).

In the Philippines, the identification and delineation of KBAs was initiated by Conservation International Philippines (CIP), the Biodiversity Management Bureau (BMB), formerly Protected Areas and Wildlife Bureau (PAWB), of the Department of Environment and Natural Resources (DENR), and the Haribon Foundation supported by Critical Ecosystem Partnership Fund (CEPF) (CIP et al. 2006). It was started in the country to support the government and other stakeholders in prioritizing and mainstreaming conservation efforts and formulating site-based strategies that protect these vulnerable and irreplaceable species within their habitats (Edgar et al. 2008).

A total of 228 KBAs were identified and delineated in the Philippines, which cover over $106,000 \mathrm{~km}^{2}$, around $35 \%$ of the total land area of the country. The ecosystem coverage of these KBAs includes the following: terrestrial only with $101 \mathrm{KBAs}\left(51,249 \mathrm{~km}^{2}\right)$; marine only with 77 KBAs $\left(19,601 \mathrm{~km}^{2}\right)$; and combinations of terrestrial and marine with $50 \mathrm{KBAs}\left(35,702 \mathrm{~km}^{2}\right)$. These KBAs are home to over 855 species, 396 of these are globally threatened species, 398 are considered restricted-range species, and 61 are congregatory species of birds (CIP et al. 2006; Ambal et al. 2012; FPE, 2020).

Hence, there is an urgent need for effective conservation and management of the remaining forest habitats of these threatened species in the country. One of the essential management strategies is through near real-time monitoring of the temporal and spatial trend of forest cover loss in these KBAs to investigate which critical habitats are more vulnerable to future degradation (Leberger et al. 2019), to identify biodiversity threats, to develop appropriate management interventions such as forest protection and reforestation, and evaluate its effectiveness (Jones et al. 2013). With the advent of remote sensing technology over the last decade, it is now possible to monitor spatial and temporal patterns of forest cover losses on a global scale using high-resolution satellite imaging (Buchanan et al. 2011; Hansen et al. 2013; Turner et al. 2003). Using remotely sensed data for forest monitoring will effectively contribute to the conservation and management of these habitats. Also, it has the potential to assess the impact of site-based policy implementation (Leberger et al. 2019).

This study aimed to quantify the spatial and temporal forest cover loss of the terrestrial KBAs in the Philippines between 2000 and 2019 using high-resolution satellite imaging of forest loss produced by Hansen et al. (2013). Also, it aimed to aid in monitoring efforts and identify the most critical terrestrial KBAs with the highest loss of forest cover - including percent loss - that need immediate intervention. A conservation priority ranking was created based on the annual rate of deforestation, which will demonstrate the applicability of the results of this study in forest monitoring of these sites. Finally, forecasting of the future trend of forest cover loss in these critical habitats was performed as well. 


\section{MATERIAL AND METHODS}

\section{Study Area}

This study was conducted in 101 identified terrestrial KBAs across the 17 regions of the Philippine archipelago with a total area of $51,298.34 \mathrm{~km}^{2}$ (Image 1) from June to October 2020. The $50 \mathrm{KBAs}$, with combined terrestrial and marine areas, were not included in the study because there is a need to delineate first the boundaries between the terrestrial and marine realms of the KBA prior to the computation of percentage forest cover of the KBA. If the boundaries will not be delineated, the marine portion of the KBA will be treated as non-forested areas and this will result in a very low percentage of forest cover although the terrestrial portion has a high percentage of forest cover. Due to the unavailability of the delineated realms of the $50 \mathrm{KBAs}$, the study was only limited to 101 terrestrial KBAs.

The Philippines, with more than 7,000 islands, is geographically located in the western Pacific Ocean and part of the southeastern Asian region which is among the biodiversity hotspots in the world with the highest concentration of terrestrial vertebrate species on the planet. According to the Foundation for the Philippine Environment (FPE) (2020), these terrestrial KBAs in the country represent several types of forest ecosystems across different elevations, namely; sub-alpine forest, mossy forest, montane forest (upper and lower), pine forest, semi-deciduous forest (moist deciduous), lowland evergreen forest, forest over limestone (karst), forest over ultrabasic soil, forest over ultramafic rocks, beach forest, and mangrove forest.

\section{DATA}

\section{Terrestrial key biodiversity areas shapefile}

To investigate the spatial and temporal forest cover loss within the study sites, the vector maps in shapefile (.shp) format of the KBAs were requested from the world database of Key Biodiversity Areas developed and maintained by BirdLife International (2020). After extracting the spatial data of terrestrial KBAs in Geographic Information System (GIS) software, the maps were compared with the web-based Philippine KBA maps using the Geoportal Philippines (2020). Based on the comparative assessment, 21 of the 101 terrestrial KBAs were observed to have notable inconsistencies in terms of area and its boundaries. Nonetheless, the 21 terrestrial KBA boundaries from the Geoportal Philippines along with the 80 terrestrial KBAs without discrepancies from Birdlife International were selected and used in the analysis of this study, which represents

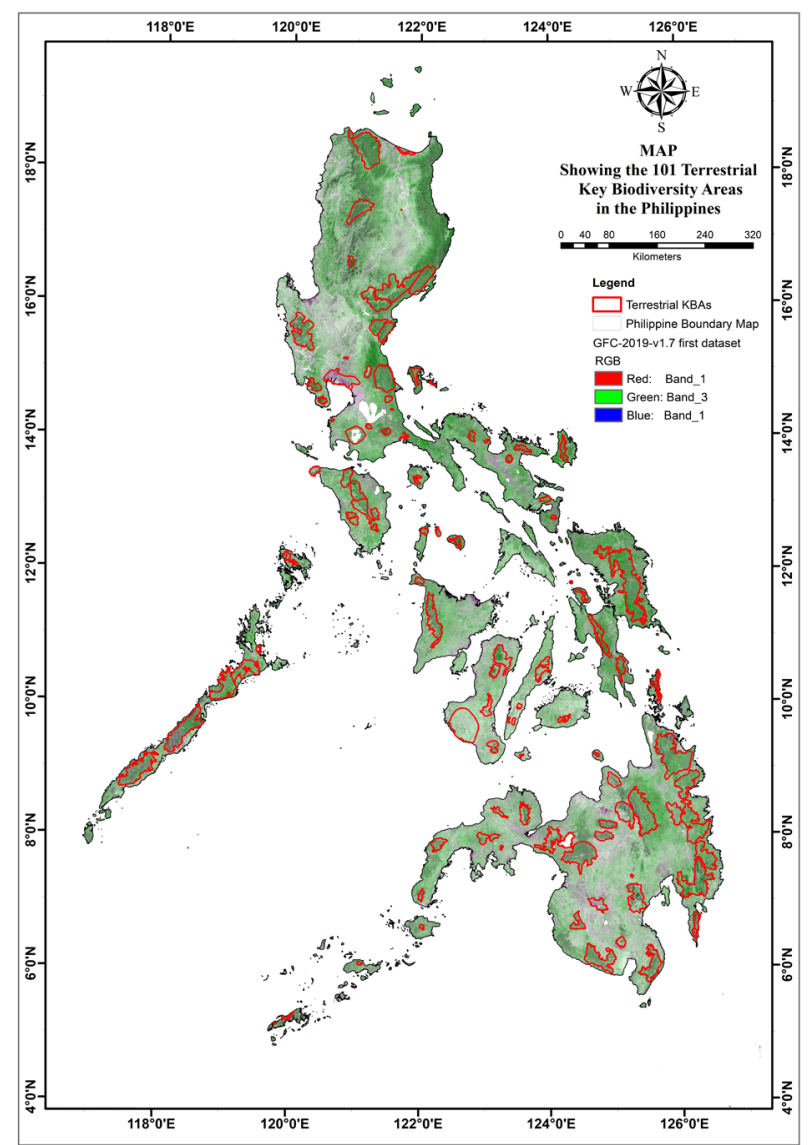

Image 1. Map showing the location of the 101 terrestrial Key Biodiversity Area study sites across the Philippine archipelago.

the best sites for biodiversity conservation.

\section{Hansen global forest change 2000-2019 version 1.7}

The main dataset in quantifying the spatial and temporal loss in forest cover of the terrestrial KBAs in the Philippines, including the initial forest cover dataset for the year 2000, is the high-resolution global maps of $21^{\text {st }}$ century forest cover change developed by Hansen et al. (2013). The product used in this study was version 1.7, which is the result of time-series analysis of Landsat data at a spatial resolution of one arc-second per pixel $(30 \mathrm{~m} \times 30 \mathrm{~m})$ depicting forest extent and change such as loss (forest to non-forest) and gain (non-forest to forest state) during the period 2000 to 2019. These data are updated annually based on a high-end remote sensing technology and can be freely downloaded from the University of Maryland - Global Land Analysis and Discovery (UM-GLAD) website as raster data. The data can also be downloaded and visualized from the Google Earth Engine (GEE) data repository. 
Geospatial processing and statistical analysis of forest cover loss

The software used to quantifying and process yearly forest cover loss of each terrestrial KBA was the Quantum Geographic Information System (QGIS) version 3.14 (pi). The KBA shapefiles were used in clipping the downloaded raster format of forest loss. After clipping, the raster datasets were converted to vector for an easier geostatistical calculation such as area determination. To facilitate the editing of the attribute data, the vector of forest cover loss was split into individual shapefiles following each KBA boundary. Finally, the area in hectares for annual forest loss per terrestrial KBA, between the periods 2001 and 2019, were calculated using the builtin calculate geometry tool. The general overview of the methodology is presented in Figure 1.

The total forest cover loss or the area change, percentage area change, and the annual rate of forest cover loss were computed using the following mathematical formulas by Hansen et al. (2013) which were also used in the study of Sulieman et al. (2017):

$$
\Delta \mathrm{A}=\mathrm{A} 2-\mathrm{A} 1
$$

where:

$\Delta \mathrm{A}=$ forest cover loss or change in the area

$\mathrm{A} 1=$ beginning of the period (date 1 )

$\mathrm{A} 2$ = end of the period (date 2 )

$$
P A C=\Delta A / T A X 100
$$

where:

$\mathrm{PAC}=$ percentage area change

$\mathrm{TA}=$ the total area of $\mathrm{KBA}$

$$
A R C=\Delta A / N
$$

where:

$\mathrm{ARC}=$ Annual rate of change (ha/year)

$\mathrm{N}=$ the number of years between date one and date two of the study period

The percentage of forest cover loss was categorized from low to high which is adapted from the study of Leberger et al. (2019). The forecasting of the future trend of forest cover loss from 2020 to 2030 was performed using the forecasting function in MS Excel based on the existing historical forest loss values.

\section{RESULTS}

\section{Spatial and temporal forest cover loss}

The forest cover of the identified terrestrial KBAs in the Philippines was estimated at around 4.5 million ha in the year 2000 , which represents $89 \%$ of the total terrestrial KBA area (Image 2). However, after almost two decades, the forest cover of these terrestrial KBAs,
Table 1. Top ten KBAs with the highest percent forest loss between 2001 and 2019.

\begin{tabular}{|l|l|c|}
\hline Region & Terrestrial Key Biodiversity Areas & $\begin{array}{c}\text { \% Forest Cover } \\
\text { Loss }\end{array}$ \\
\hline BARMM & Tawi-tawi Island & 27.88 \\
\hline XIII, XI & Bislig & 25.75 \\
\hline IX & Mount Sugarloaf & 19.24 \\
\hline IV-B & Mount Mantalingahan & 17.14 \\
\hline IX & Lituban-Quipit Watershed & 14.98 \\
\hline IV-B & Malpalon & 13.01 \\
\hline IV-B & San Vicente-Roxas Forests & 11.96 \\
\hline XI & Mount Agtuuganon and Mount Pasian & 11.76 \\
\hline IV-B & Mount Calavite & 11.49 \\
\hline IX & Mount Dapiak and Mount Paraya & 11.11 \\
\hline
\end{tabular}

Table 2. Percentage frequency distribution of forest loss in the study sites.

\begin{tabular}{|l|c|c|}
\hline Classification & $\begin{array}{c}\text { Percentage of forest } \\
\text { loss }\end{array}$ & Frequency \\
\hline Low & $0-0.76$ & 3 \\
\hline Moderate & $0.77-3.13$ & 40 \\
\hline High & $>3.13$ & 58 \\
\hline Total & & 101 \\
\hline
\end{tabular}

based on the GIS analysis of high-resolution remotely sensed data developed by Hansen et al. (2013), had decreased by around 270,000 ha, which is almost $6 \%$ of the total forest cover in the year 2000. It is estimated that the remaining forest cover within these terrestrial KBAs as of 2019 is around $81 \%$ with an area of 4.27 million ha. Moreover, the annual rate of forest cover loss for these priority areas for biodiversity conservation is computed at around 14,213 ha/year with an annual average deforestation rate of $6 \%$ (Image 3 ).

The scatter plot shows an increasing trend in the annual forest cover loss from 2001 to 2019. The period with the highest recorded rate of deforestation was between 2016 and 2017, but on a positive note, there has been a notable decrease of these losses in the last two consecutive years (2018 and 2019) (Figure 2).

The 10 terrestrial KBAs with the highest percentage of forest loss between 2000 and 2019, except for the KBAs with lake environments (Malasi Lake and Mungao Lake), are presented in Table 1 . The percentage of forest loss was highest in Tawi-tawi Island, located in Bangsamoro Autonomous Region in Muslim Mindanao (BARMM) with $27.88 \%$. Based on the percentage frequency distribution presented in Table 2, the majority of the study sites (58) 


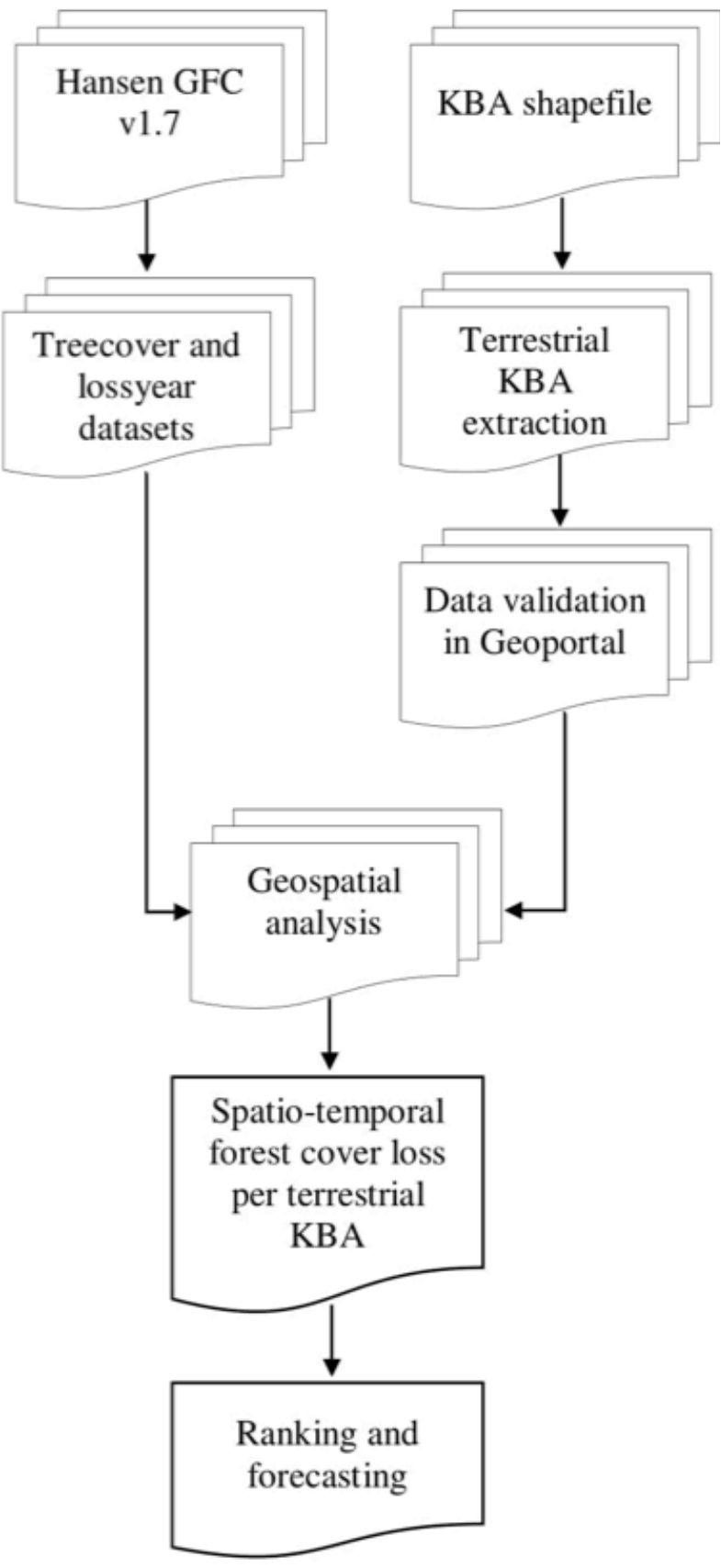

Figure 1. General overview of the methodology.

had a high percentage of forest loss with more than $3.13 \%$. On the other hand, only three (3) among the 101 terrestrial KBAs had low percentage of loss, these are Timpoong and Hibok-hibok Natural Monument in Region 10, Mounts Banahaw and San Cristobal Protected Landscape in Region 4A, and Mount Kitanglad in Region 10 , with $0.31 \%, 0.27 \%$, and $0.24 \%$, respectively.

The KBA with the highest net loss of forest area in nearly two decades was Bislig, located in Region 13 covering some portion of Region 11, which was around
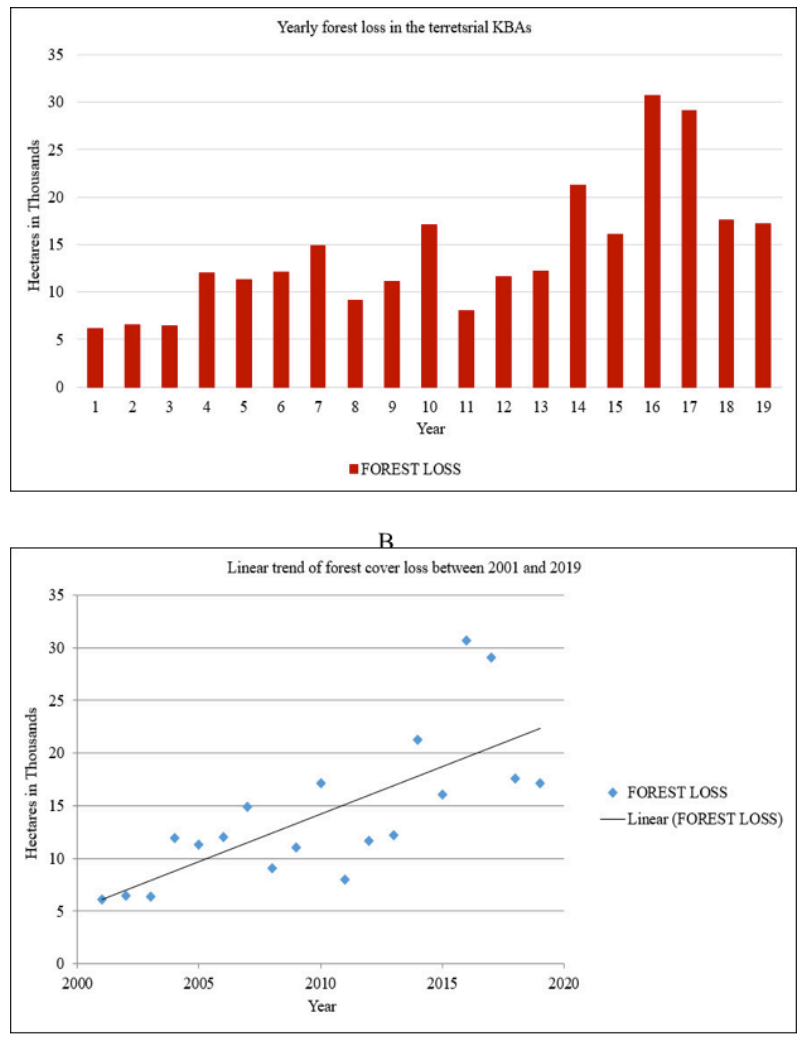

A

Figure 2. Forest cover loss in terrestrial key biodiversity areas: AAnnual loss | B-The linear trend of forest cover loss in nearly two decades.

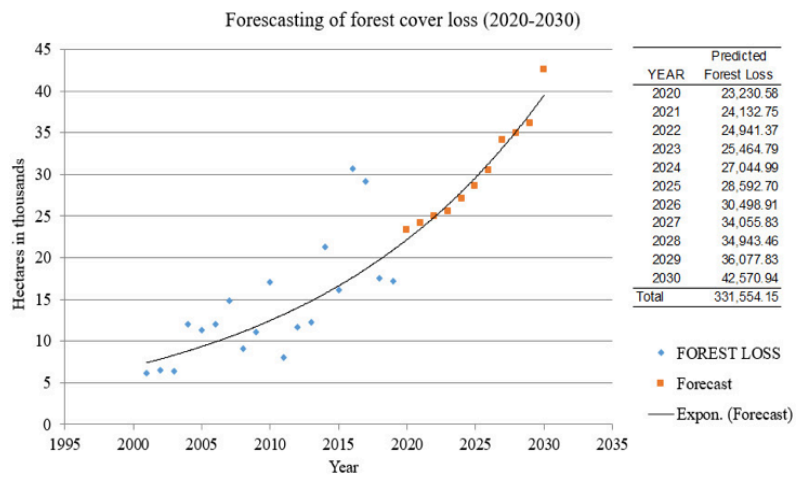

Figure 3. Forecast of forest cover loss in terrestrial key biodiversity areas.

38.5 thousand ha (Table 3), while the Timpoong and Hibok-hibok Natural Monument had the lowest area of forest loss (except for KBAs with lake environment) with only 10.59 ha in two decades. Moreover, the Bislig KBA also had the highest annual rate of deforestation with a loss of 2,031 hectares per year (ha/year). This was followed by Mount Mantalingahan in Region 4B and Samar Island Natural Park in Region 8, with 1,266 ha/ 
Table 3. Top ten sites with the highest forest loss between 2001 and 2019.

\begin{tabular}{|l|l|c|}
\hline Region & Terrestrial Key Biodiversity Areas & Forest cover loss (ha) \\
\hline XIII, XI & Bislig & $38,589.02$ \\
\hline IV-B & Mount Mantalingahan & $24,071.86$ \\
\hline VIII & Samar Island Natural Park & $14,037.57$ \\
\hline CAR, II, I & Apayao Lowland Forest & $12,384.94$ \\
\hline XIII & Mount Diwata Range & $10,146.78$ \\
\hline XI & Mount Agtuuganon and Mount & $9,989.77$ \\
\hline XIII & Masian & $9,842.84$ \\
\hline II & Quirino Protected Landscape & $9,610.57$ \\
\hline IV-B & San Vicente-Roxas Forests & $9,221.44$ \\
\hline IV-B & Victoria and Anepahan Ranges & $8,742.57$ \\
\hline
\end{tabular}

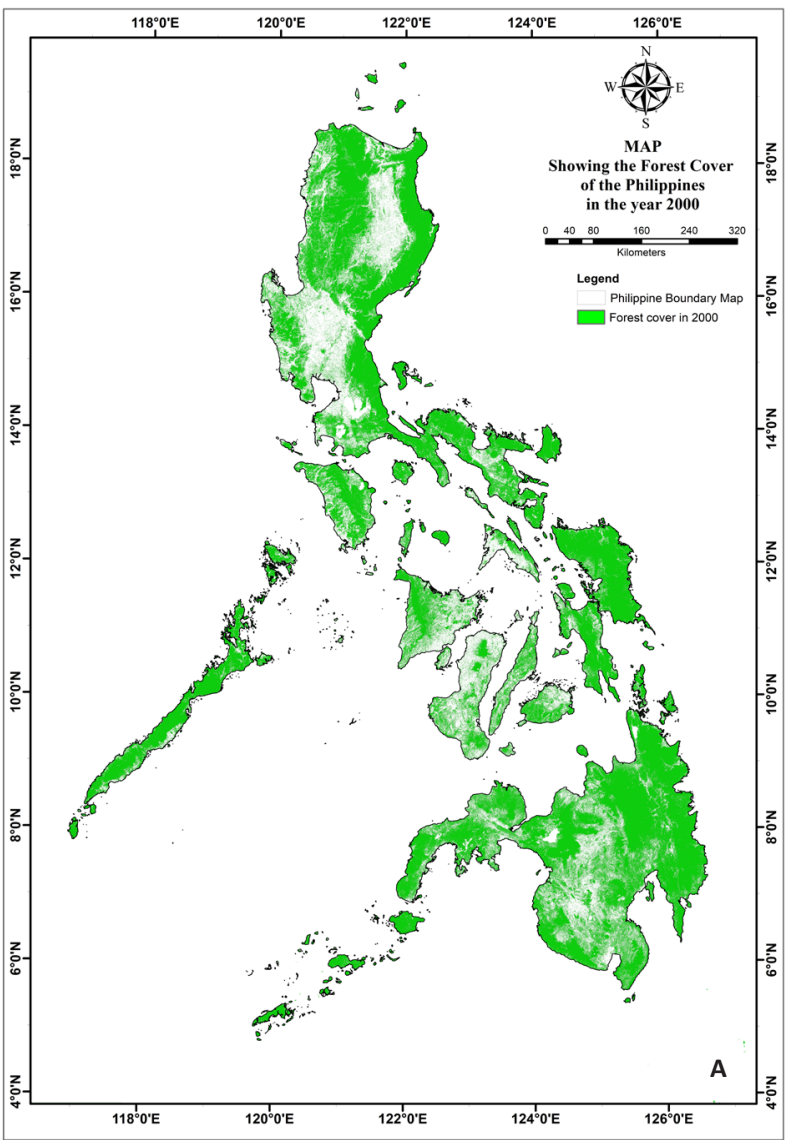

Table 4. Top ten sites with the highest annual rate of deforestation.

\begin{tabular}{|l|l|c|}
\hline Region & Terrestrial Key Biodiversity Areas & $\begin{array}{c}\text { Annual rate of forest } \\
\text { cover loss (ha/year) }\end{array}$ \\
\hline XIII, XI & Bislig & $2,031.00$ \\
\hline IV-B & Mount Mantalingahan & $1,266.94$ \\
\hline VIII & Samar Island Natural Park & 738.82 \\
\hline CAR, II, I & Apayao Lowland Forest & 651.84 \\
\hline XIII & Mount Diwata Range & 534.04 \\
\hline XI & $\begin{array}{l}\text { Mount Agtuuganon and Mount } \\
\text { Pasian }\end{array}$ & 525.78 \\
\hline XIII & Mount Hilong-hilong & 518.04 \\
\hline II & Quirino Protected Landscape & 505.82 \\
\hline IV-B & San Vicente-Roxas Forests & 485.34 \\
\hline IV-B & Victoria and Anepahan Ranges & 460.14 \\
\hline
\end{tabular}

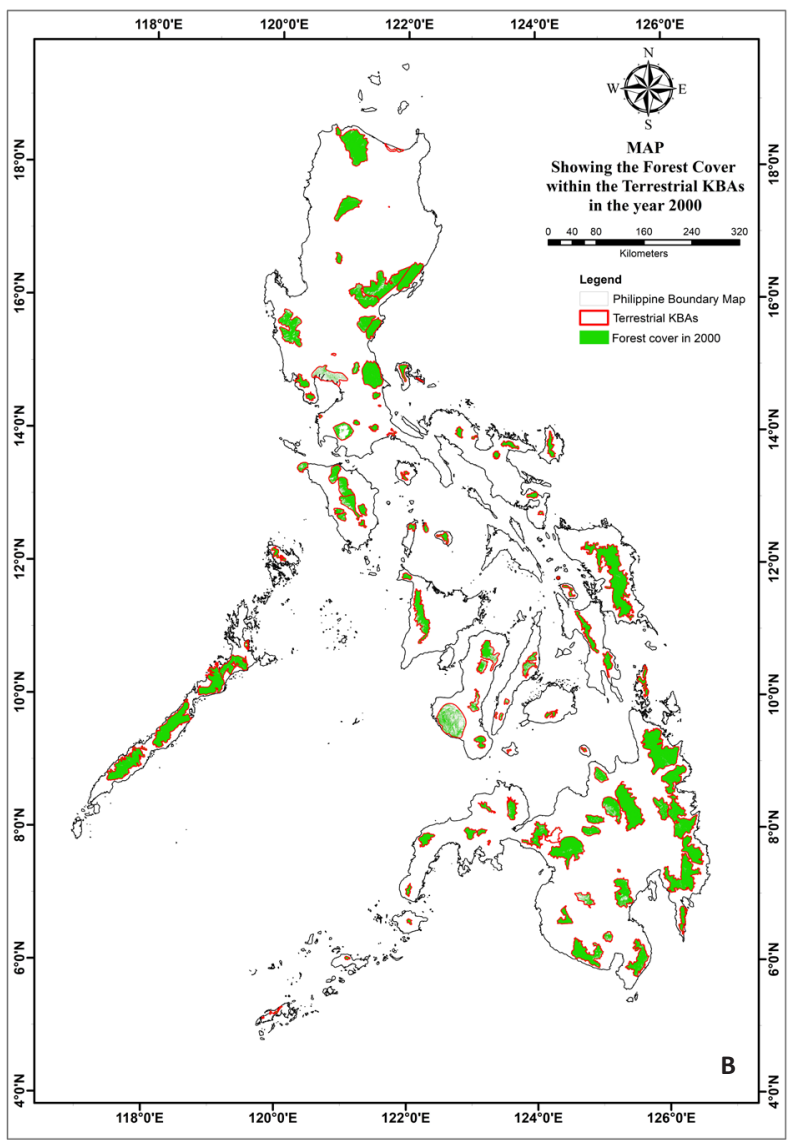

Image 2. Forest cover in the year 2000: A-Nationwide | B-Within terrestrial KBAs.

year and $738.82 \mathrm{ha}$ /year forest loss, respectively (Table 4). The conservation priority ranking of the 101 terrestrial KBAs, ranked in terms of forest cover loss and the annual rate of deforestation, is presented in Appendix 1 . This also includes relevant information such as the region and area of KBAs, forest cover and percent forest cover in the year 2000 and 2019, and percent forest cover loss. 


\section{DISCUSSION}

Quantification of spatial and temporal forest cover loss using Hansen remotely sensed data

In the Philippines, the use of remote sensing for annual forest cover monitoring and loss detection in terrestrial KBAs, even on the national scale, is not yet fully developed compared to other tropical countries like Brazil (Instituto Nacional de Pesquisas Espaciais 2010) and India (Forest Survey of India 2019). Thus, remotely sensed satellite imagery, such as the dataset produced by Hansen et al. (2013), can contribute significantly to biodiversity monitoring (Tracewski et al. 2016). However, errors are inevitable for these datasets, for example, forest loss estimation in dry forests may be underestimated, as reported by Achard et al. (2014), but are working well enough in moist humid forest. Also, the accuracy assessment conducted by Mitchard et al. (2015) in Ghana showed a significant underestimation of forest change. Another limitation in the dataset is that it does not distinguish permanent deforestation from temporary forest disturbance like forest fires, forestry plantations, and shifting cultivation (Curtis et al. 2018). Nevertheless, the overall accuracy of forest cover loss of Hansen GFC dataset as shown in different studies is between $88 \%$ (Feng et al. 2016) to 93\% (Hirschmugl et al. 2020) and it represents the best high-resolution, with $30 \mathrm{~m} \times 30 \mathrm{~m}$ spatial resolution, global assessment of forest cover change that is freely accessible to the public (Hansen et al. 2010; Tracewski et al. 2016).

\section{Critical habitat conservation priorities}

The Tawi-tawi Island, identified in this study with the highest percent forest loss (27.88\%) among the terrestrial KBAs, was also recognized as one of the Alliance for Zero Extinction (AZE) sites (AZE 2010) that holds two critically endangered (CR) species and one endangered (EN) species (IUCN 2008). The AZE sites are those that have threatened species constrained to just a single site globally (AZE 2010). Also, this KBA has 45 trigger species identified (Odevillas 2018). Trigger species are those that trigger either the irreplaceability criterion or vulnerability criterion within the KBAs (Langhammer et al. 2007), these could also be identified by combining both the endemism and rarity criteria (Yahi et al. 2012). Based on the findings of this study, 58 sites recorded a high percentage forest loss which suggests that these areas should be prioritized in terms of forest conservation and protection. It is also advisable that the strategies and good practices in forest conservation of the three (3) sites with the lowest percentage of forest loss should be adapted to other sites of this study.

The second site with the highest percent forest loss, which also had the highest annual deforestation rate, and with the largest area of forest cover loss within the study period is the Bislig KBA in Region 13 (Image 4). This terrestrial KBA has 33 trigger species and one (1) critically endangered species based on the data from the Haribon Foundation (2020) and red list of threatened species (IUCN 2008).

Mount Mantalingahan in Region 4B, with a total of 24,071.86 ha of forest cover loss between 2001 and 2019 and an annual deforestation rate of 1,266 ha/year, has one (1) endangered species, one (1) vulnerable species (Ambal et al. 2012), and 38 trigger species (Odevillas 2018). Although this KBA was already removed from the AZE list in 2010 after the Palawanomys furvus was reclassified as Data Deficient from Endangered (EN) species in 2008 (Ambal et al. 2012), the threat to biodiversity remains. This is mainly due to its high annual rate of forest cover loss as observed in this study.

The Samar Island National Park in Region 8, which ranked third in this study with the highest rate of forest cover loss, was also identified as a top priority site for protection due to its large number of trigger species with 180 species in total, and three (3) critically endangered species (Odevillas 2018). These findings suggest that the aforementioned terrestrial KBAs are more likely to experience species extinction in the coming decades without proper conservation and protection measures.

\section{Status and trends of forest cover in the terrestrial key biodiversity areas in the Philippines}

The identified terrestrial KBAs in the Philippines cover at least $17 \%$ of the estimated total land area of the country ( 30 million ha) and were declared as "critical habitats" under the Presidential Executive Order 578 in 2006. However, these sites alone are not enough for biodiversity conservation (FAO \& UNEP 2020) especially in a country regarded as one of the top global biodiversity hotspots (Mittermeier et al. 1998). Therefore, an expansion of these habitats is necessary to increase conservation coverage of the threatened species (Kullberg et al. 2019). Also, there are only 27 protected terrestrial KBAs, 25 are partially protected, while the remaining 49 are unprotected or not covered with any legislative interventions (Ambal et al. 2012), which make these areas more vulnerable to anthropogenic deforestation that has a remarkable effect on forest cover (Margono et al. 2014). However, even a protected KBA is still vulnerable to land cover conversion for agroindustrial use, as observed in the buffer zones of Mount 

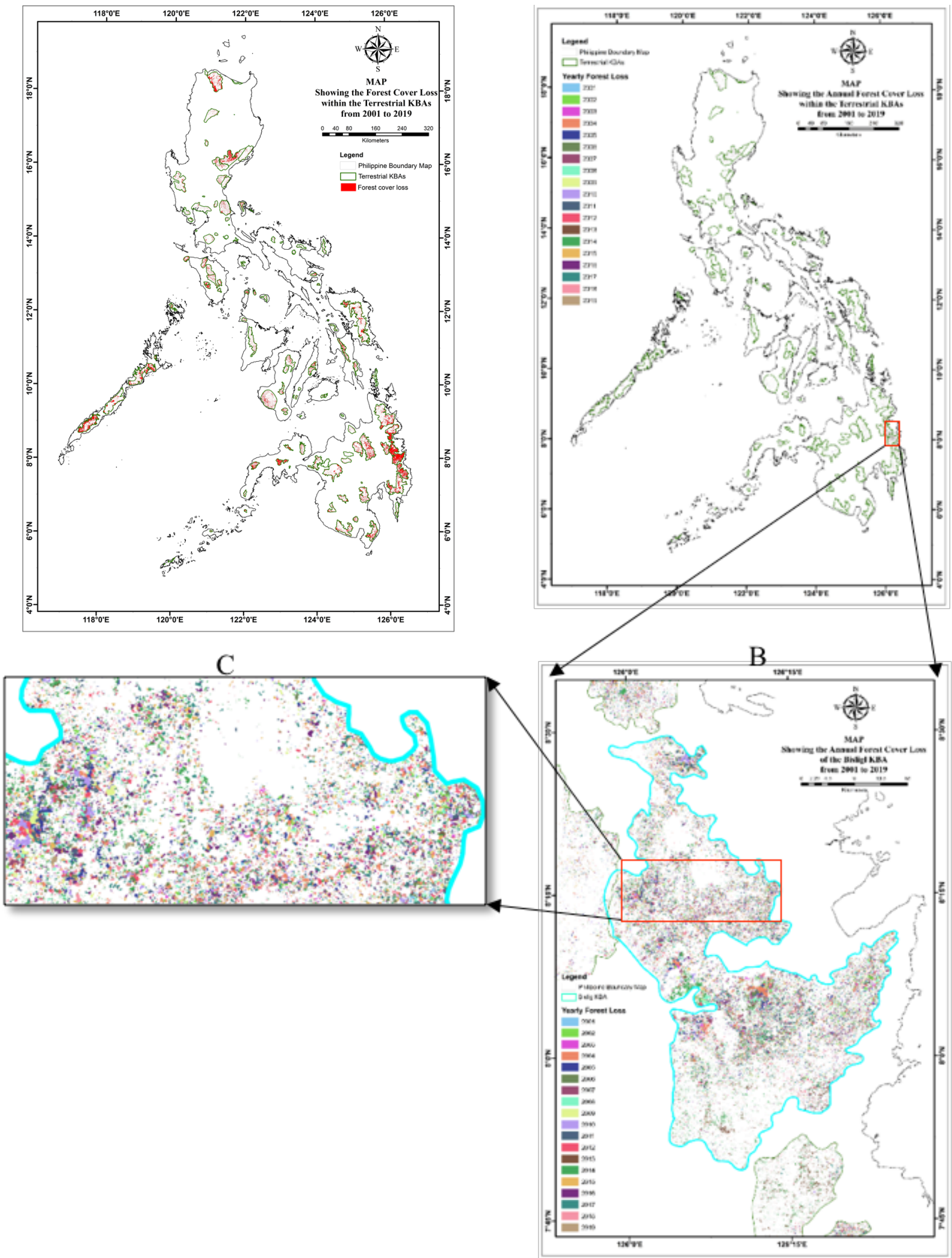

A

Image 3. Map showing the forest cover loss within the Philippines' terrestrial key biodiversity areas: A-The total forest loss from 2001 to 2019 | B-The annual forest loss from 2001 to 2019 | C-The annual forest loss of Bislig Key Biodiversity Area. 


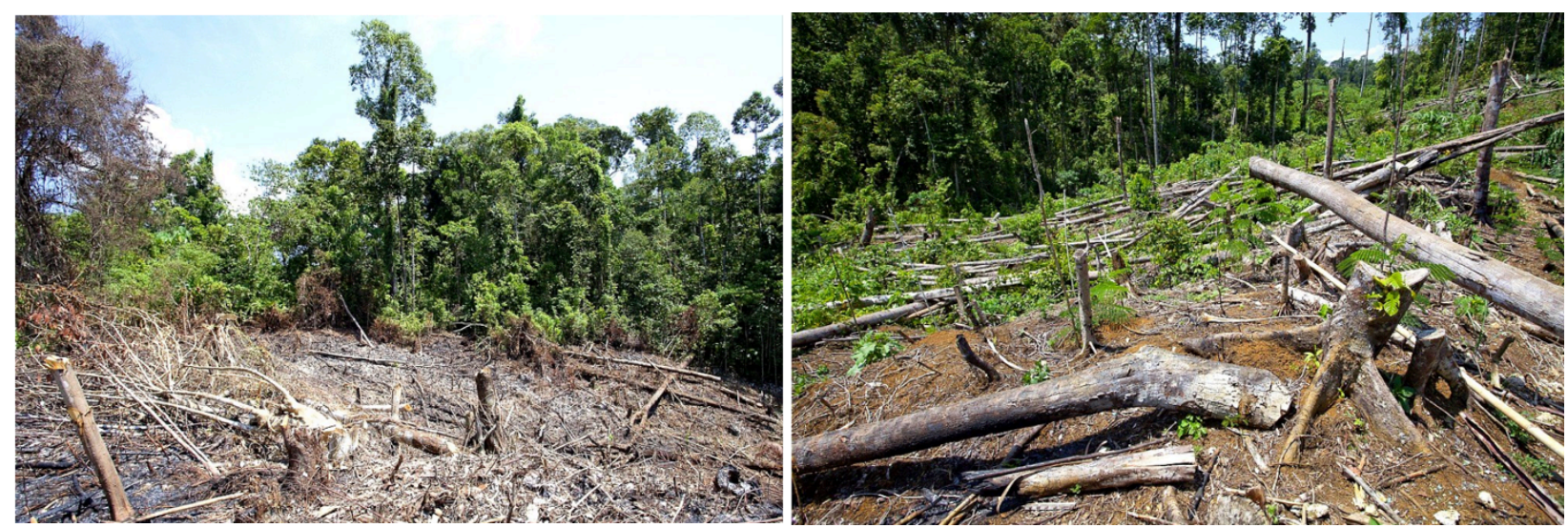

Image 4. The deforestation area in Bislig Key Biodiversity Area. @ Francesco Veronesi.

Kalatungan (Azuelo \& Puno 2018).

As reported by the DENR (2000) in its 2000 Philippine Forestry Statistics (PFS), the country's forest cover was around 5.4 million ha in the year 2000 (18\% of the total land area), which implies that $83 \%$ of these forests were found in the terrestrial KBAs. Although forest cover increased in the country between 2000 and 2015, with an estimated area of seven million ha or a $22 \%$ increase (DENR 2019), a consistent decline in the forest cover of these terrestrial KBAs was detected in this study within the same period. The decline in forest cover in the country is also reported by Mongabay (2020) based on deforestation statistics stating that a total of 1,128,788 ha of forest was lost between 2001 and 2018. Globally, the rates of forest cover loss in Important Birds and Biodiversity Areas (IBAs) were highest in South America and southeastern Asia (Tracewski et al. 2016), which includes the Philippines. This indicates that the country's efforts in managing and protecting these critical habitats, as well as the existing environmental protection measures, are seriously inadequate (Oliver \& Heaney 1996; Hammond 1997) due to the constant rate of deforestation and forest degradation within these areas, which are generally caused by logging, mining, and land conversion (from forest to non-forest) (Lillo et al. 2018). Although a promising finding was observed in the last two periods ( 2018 \& 2019) due to the substantial decreased in the forest cover loss, there is still a need for annual forest cover loss monitoring to identify and evaluate the impact of policy and conservation interventions in the spatial and temporal forest cover loss in these areas (Broich et al. 2011).

Since the forest cover loss of the study sites exhibited an increasing trend, with a similar pattern of results obtained in the study of Leberger et al. (2019) on a global scale, it is predicted in this study that by the end of 2030 an area of approximately 331,000 ha of forest will be lost, equivalent to around $7.3 \%$ of the total forest cover in these sites (Figure 3). This immense decline in forest will leave these critical habitats with only $76 \%$ remaining cover, and in turn escalate the threat to the 25 Critically Endangered (CR), 40 Endangered (EN), and 117 Vulnerable (VU) species (Ambal et al. 2012) found in these sites. Unless there is a transformational change in the way the country manages and conserves its forests and biodiversity (FAO \& UNEP 2020) through these terrestrial KBAs, extinction of species is imminent. For that reason, there is an undeniable need for near real-time monitoring of forest loss within these areas (Leberger et al. 2019), and ranking/prioritizing them for conservation based on vulnerability to degradation (Brooks et al. 2006).

\section{CONCLUSION}

The present study quantified the spatial and temporal pattern of forest cover loss in 101 terrestrial key biodiversity areas of the Philippines between the periods 2001 and 2019 using high-resolution satellitebased earth observation datasets. Remote sensing technology and geospatial analysis have a high potential for timely monitoring of the forest cover status of these habitats, an essential component of biodiversity conservation. The increasing trend of forest loss in the terrestrial KBAs, as observed in this study, with an annual deforestation rate of about 14,213 ha per year, clearly suggests that the efforts in the conservation of these critical habitats need recalibration. Thus a paradigm shift is necessary to manage these sites in an attempt to prevent the extinction of 182,000 species or at least improve their conservation status. There is also a need 
to expand the terrestrial KBAs in the country taking into consideration the threatened species of vascular plants since the identification and delineation of terrestrial KBAs was only based on some faunal taxonomic groups, such as amphibians, reptiles, birds, and mammals.

\section{REFERENCES}

Achard, F., R. Beuchle, P. Mayaux, H.J. Stibig, C. Bodart \& A. Brink (2014). Determination of tropical deforestation rates and related carbon losses from 1990 to 2010. Global Change Biology 20: 2540e. https://doi.org/10.1111/gcb.12605

Aerts, R. \& O. Honnay (2011). Forest restoration, biodiversity and ecosystem functioning. BMC Ecology 11: 29. https://doi. org/10.1186/1472-6785-11-29

Alliance for Zero Extinction (2010). http://www.zeroextinction.org. Accessed 3 August 2020

Ambal, R.G., M. Duya, M.A. Cruz, O. Coroza, S. Vergara, N. De Silva, N. Molinyawe \& B. Tabaranza (2012). Key biodiversity areas in the Philippines: priorities for conservation. Journal of Threatened Taxa 4(8): 2788-2796. https://doi.org/10.11609/JoTT.o2995.2788-96

Azuelo, A.G. \& G.R. Puno (2018). Moss and lichen diversity in Mt. Kalatungan Range Natural Park, Bukidnon, Philippines. International Journal of Biosciences 12(3): 248-258. https://doi.org/10.12692/ $\mathrm{ijb} / 12.3 .248-258$

BirdLife International (2020). World database of key biodiversity areas. Developed by the KBA Partnership. www.keybiodiversityareas.org. Accessed 2 July 2020.

Broich, M., M. Hansen, F. Stolle, P. Potapov, B.A. Margono \& B Adusei (2011). Remotely sensed forest cover loss shows high spatial and temporal variation across Sumatera and Kalimantan Indonesia 2000-2008. Environmental Research Letters 6: 1. https:// doi.org/10.1088/1748-9326/6/1/014010

Brooks, T., R.A. Mittermeier, G. Fonseca, J. Gerlach, M. Hoffmann, J. Lamoreux, C. Mittermeier, J. Pilgrim \& A. Rodrigues (2006). Global biodiversity conservation priorities. Science 313: 58-61.

Brooks, T.M., R.A. Mittermeier, C.G. Mittermeier, G.A.B. Da Fonseca, A.B. Rylands, W.R. Konstant, P. Flick, J. Pilgrim, S. Oldfield, G. Magin \& C. Hilton-Taylor (2002). Habitat loss and extinction in the hotspots of biodiversity. Conservation Biology 16(4): 909-923. https://doi.org/10.1046/j.1523-1739.2002.00530.x

Buchanan, G.M., P.F. Donald \& S.H.M. Butchart (2011). Identifying priority areas for conservation: a global assessment for forestdependent birds. PLOSONE 6(12): e29080. https://doi.org/10.1371/ journal.pone.0029080

Conservation International Philippines (2020). Primer on Philippine Biodiversity. https://www.conservation.org/philippines. Electronic version accessed 20 December 2020.

Conservation International Philippines, DENR-PAWB \& Haribon (2006). Priority sites for conservation in the Philippines: key biodiversity areas. Quezon City, Philippines. https://www.slideshare. net/no2mininginpalawan/priority-sites-for-conservation-in-thephilippines-key-biodiversity-areas-kbas. Accessed 20 July 2020.

Cucinotta, D. \& M. Vanelli (2020). WHO declares COVID-19 a pandemic. Acta Biomed 91(1): 157-160. https://doi.org/10.23750/ abm.v91i1.9397

Curtis, P.G., C.M. Slay, N.L. Harris, A. Tyukavina \& M.C. Hansen (2018). Classifying drivers of global forest loss. Science 361(6407): 11081111. https://doi.org/10.1126/science.aau3445

Department of Environment and Natural Resources (DENR) (2000). Philippine forestry statistics 2000. Forest Managemen Bureau. Quezon City, Philippines. https://drive.google.com/file/ d/OB1G5mTNoDPOFT01hZGROYnZPcmc/view. Downloaded on 5 August 2020

Department of Environment and Natural Resources (DENR) (2019).
Philippine forestry statistics 2019. Forest Management Bureau. Quezon City, Philippines. https://forestry.denr.gov.ph/index.php/ statistics/philippines-forestry-statistics. Downloaded on 5 August 2020.

Driscoll, D.A., L.M. Bland, B.A. Bryan, T.M. Newsome, E. Nicholson, E.G. Ritchie \& T.S. Doherty (2018). A biodiversity-crisis hierarchy to evaluate and refine conservation indicators. Nature Ecology and Evolution 2: 775-781. https://doi.org/10.1038/s41559-018-0504-8

Drummond, M.A. \& T.R. Loveland (2010). Land-use pressure and a transition to forest-cover loss in the eastern United States. BioScience 60(4): 286-298. https://doi.org/10.1525/bio.2010.60.4.7

Edgar, G.J., P.F. Langhammer, G. Allen, T.M. Brooks, J. Brodie, W. Crosse, N. De Silva, L. Fishpool, M.N. Foster, D. Knox, J.E. McCosker, R. McManus, A. Miller \& R. Mugo (2008). Key biodiversity areas as globally significant target sites for the conservation of marine biological diversity. Aquatic Conservation: Marine and Freshwater Ecosystems 18: 969-983. https://doi.org/10.1002/aqc.902

Eken, G., L. Bennun, T.M. Brooks, W. Darwall, L.D.C. Fishpool, M. Foster, D. Knox, P. Langhammer, P. Matiku, E. Radford, P. Salaman, W. Sechrest, M.L. Smith, S. Spector \& A. Tordoff (2004). Key Biodiversity Areas as site conservation targets. BioScience 54(12): 1110-1118. https://doi.org/10.1641/0006-3568(2004)054[1110:KB AASC]2.0.CO;2

Estavillo, C., R. Pardini \& P.L.B. Rocha (2013). Forest loss and the biodiversity threshold: an evaluation considering species habitat requirements and the use of matrix habitats. PLOS ONE 8(12): e82369. https://doi.org/10.1371/journal.pone.0082369

FAO \& UNEP (2020). The State of the World's Forests 2020. Forests, Biodiversity and People. Rome. Downloaded on 10 July 2020. https://doi.org/10.4060/ca8642en

Feng, M., J.O. Sexton, C. Huang, A. Anand, S. Channan, X.P. Song, D.X. Song, D.H. Kim, P. Noojipady \& J.R. Townshend (2016). Earth science data records of global forest cover and change: Assessment of accuracy in 1990, 2000, and 2005 epochs. Remote Sensing of Environment 184: 73-85. https://doi.org/10.1016/j.rse.2016.06.012

Foley, J.A., R. Defries, G.P. Asner, C. Barford, G. Bonan, S.R. Carpenter, F.S. Chapin, M.T. Coe, G.C. Daily, H.K. Gibbs, J.H. Helkowski, T. Holloway, E.A. Howard, C.J. Kucharik, C. Monfreda, J.A. Patz, I.C. Prentice, N. Ramankutty \& P.K. Snyder (2005). Global consequences of land use. Science 309: 570-574. https://doi.org/10.1126/ science.1111772

Foundation for the Philippine Environment (2020). The Philippine key biodiversity areas (KBAs). https://fpe.ph/biodiversity.html/ view/the-philippine-key-biodiversity-areas-kbas. Electronic version accessed 15 July 2020.

Forest Survey of India (2019). India State of Forest Report (ISFR) 2019. Dehra Dun, India: Ministry of Environment and Forest. https://www. drishtiias.com/daily-updates/daily-news-analysis/india-state-offorest-report-isfr-2019. Electronic version accessed 25 August 2020.

Gaither, M.R. \& L.A. Rocha (2013). Origins of species richness in the Indo-Malay-Philippine biodiversity hotspot: evidence for the centre of overlap hypothesis. Journal of Biogeography 40(9): 1638-1648. https://doi.org/10.1111/jbi.12126

Geoportal Philippines (2020). Key Biodiversity Areas Map. http:// www.geoportal.gov.ph/. Electronic version accessed 5 July 2020.

Gibson, L., T.M. Lee, L.P. Koh, B.W. Brook, T.A. Gardner, J. Barlow, C. Peres, C.J.A. Bradshaw, W.F. Laurance, T.E. Lovejoy \& N.S. Sodhi (2011). Primary forests are irreplaceable for sustaining tropical biodiversity. Nature 478: 378-381. https://doi.org/10.1038/ nature 10425

Hammond, D. (1997). Asia-Pacific forestry sector outlook study: commentary on forest policy in the Asia-Pacific region (A review for Indonesia, Malaysia, New Zealand, Papua New Guinea, Philippines, Thailand and Western Samoa). Food and Agriculture Organization (FAO) of the United Nations. http://www.fao.org/3/w7730e/ w7730e00.htm\#Contents. Downloaded on 25 July 2020.

Hansen, M.C., P.V. Potapov, R. Moore, M. Hancher, S.A. Turubanova, A. Tyukavina, D. Thau, S.V. Stehman, S.J. Goetz, T.R. Loveland, A. Kommareddy, A. Egorov, L. Chini, C.O. Justice \& J.R.G. Townshend 
(2013). High-resolution global maps of 21st-century forest cover change. Science 342(6160): 850-853. https://doi.org/10.1126/ science. 1244693

Hansen, M.C., S.V. Stehman \& P.V. Potapov (2010). Quantification of global forest cover loss. Proceedings of the National Academy of Sciences 107(19): 8650-8655. https://doi.org/10.1073/ pnas.0912668107

Haribon Foundation (2020). Research data on the Philippine key biodiversity areas (KBAs). https://haribon.org.ph/category/ research/. Electronic version accessed 25 August 2020

Hirschmugl, M., J. Deutscher, C. Sobe, A. Bouvet, S. Mermoz \& M. Schardt (2020). Use of SAR and optical time series for tropical forest disturbance mapping. Remote Sensing 12: 727. https://doi. org/10.3390/rs12040727

Hilton-Taylor, C., C.M. Pollock, J.S. Chanson, S.H.M. Butchart, T.E.E. Oldfield \& V. Katareya (2009). State of the world's species, pp. 15-41. In: Vie' J-C., C. Hilton-Taylor \& S.N. Stuart (eds.). Wildlife in a Changing World - An Analysis of the 2008 IUCN Red List of Threatened Species. IUCN, Gland, Switzerland.

Instituto Nacional de Pesquisas Espaciais (2010). Deforestation Estimates in the Brazilian Amazon. http://www.obt.inpe.br/prodes/. Electronic version accessed 20 September 2020.

International Union for the Conservation of Nature (2008). The 2008 IUCN red list of threatened species. http://www.redlist.org. Electronic version accessed 10 August 2020.

International Union for the Conservation of Nature (2016). A global standard for the identification of key biodiversity areas. https:// portals.iucn.org/library/sites/library/files/documents/Rep-2016005.pdf. Downloaded on 13 August 2020.

Jones, J.P.G., G.P. Asner, S.H.M. Butchart \& K.U. Karanth (2013) The 'why', 'what' and 'how' of monitoring for conservation, pp. 327-343. In: MacDonald, D.W. \& K.J. Willis (eds.) Key Topics in Conservation Biology. Wiley-Blackwell, Cambridge. https://doi. org/10.1002/9781118520178.ch18

Kullberg, P., E.D. Minin \& A. Moilanen (2019). Using key biodiversity areas to guide effective expansion of the global protected area network. Global Ecology and Conservation 20: e00768. https://doi. org/10.1016/j.gecco.2019.e00768

Langhammer, P.F., M.I. Bakarr, L.A. Bennun, T.M. Brooks, R.P. Clay, W. Darwall, N. De Silva, G.J. Edgar, G. Eken, L.D.C. Fishpool, G.A.B. Fonseca, M.N. da Foster, D.H. Knox, P. Matiku, E.A. Radford A.S.L. Rodrigues, P. Salaman, W. Sechrest \& A.W. Tordoff (2007). Identification and gap analysis of key biodiversity areas: targets for comprehensive protected area systems. IUCN World Commission on Protected Areas Best Practice Protected Area Guidelines Series No. 15. IUCN, Gland, Switzerland. https://doi.org/10.2305/IUCN. CH.2006.PAG.15.en

Leberger, R., I.M.D. Rosa, C.A. Guerra, F. Wolf \& H.M. Pereira (2019). Global pattern of forest loss across IUCN categories of protected areas. Journal of Biological Conservation 241: 108299. https://doi. org/10.1016/j.biocon.2019.108299

Levi, T., A.L. Massey, R.D. Holt, F. Keesing, R.S. Ostfeld \& C.A. Peres (2016). Does biodiversity protect humans against infectious disease? Comment. Ecology 97(2): 536-546. https://doi.org/10.1890/15354.1

Lillo, E.P., E.S. Fernando \& M.J.R. Lillo (2018). Plant diversity and structure of forest habitat types on Dinagat Island, Philippines. Journal of Asia-Pacific Biodiversity 12 (2019): 83-105. https://doi. org/10.1016/j.japb.2018.07.003

Margono, B.A., P.V. Potapov, S. Turubanova, F. Stolle \& M.C. Hansen (2014). Primary forest cover loss in Indonesia over 2000-2012. Nature Climate Change 4: 730-735. https://doi.org/10.1038/ nclimate 2277
Melovski, L.J., M. Velevski, V. Matevski, V. Avukatov \& A. Sarov (2012). Using important plant areas and important bird areas to identify key biodiversity areas in the Republic of Macedonia. Journal of Threatened Taxa 4(8): 2766-2778. https://doi.org/10.11609/ JoTT.02997.2766-78

Mitchard, E., K. Viergever, V. Morel \& R. Tipper (2015). Assessment of the accuracy of University of Maryland (Hansen et al..) forest loss data in 2 ICF project areas - component of a project that tested an ICF indicator methodology. Final Report. Ecometrica. The University of Edinburgh. https://ecometrica.com/wp-content/uploads/2015/08/ UMD_accuracy_assessment_website_report_Final.pdf. Electronic version accessed 12 September 2020.

Mittermeier, R.A., N. Myers, J.B. Thomsen, G.A.B. Da Fonseca \& S. Olivieri (1998). Biodiversity hotspots and major tropical wilderness areas: approaches to setting conservation priorities. Conservation Biology 12: 516-520. https://doi.org/10.1046/j.15231739.1998.012003516.x

Mongabay (2020). Deforestation statistics for the Philippines. https:// rainforests.mongabay.com/deforestation/archive/Philippines.htm. Electronic version accessed 15 September 2020.

Odevillas, V.A. (2018). Multi-criteria spatial analysis of key biodiversity areas (KBAs) in the Philippines. Haribon Foundation. https:// haribon.org.ph/spatial-analysis-of-important-bird-area-boundariesin-the-philippines-gaps-and-recommendations-2/. Electronic version accessed 15 July 2020.

Oliver, W.L.R. \& L. Heaney (1996). Biodiversity and conservation in the Philippines. International Zoo News 43: 329-337.

Sulieman, M.S., O.V. Wasonga, J.S. Mbau \& Y.A. Elhadi (2017). Spatial and temporal analysis of forest cover change in Falgore Game Reserve in Kano, Nigeria. Ecological Processes 6: 1. https://doi. org/10.1186/s13717-017-0078-4

Tracewski, L., H.M. Stuart, P.F. Butchart, M.E. Donald, D.C. Lincoln, G.M. Fishpool \& G.M. Buchanan (2016). Patterns of twenty-first century forest loss across a global network of important sites for biodiversity. Remote Sensing in Ecology and Conservation 2(1): 3744. https://doi.org/10.1002/rse2.13

Turner, W., S. Spector, N. Gardiner, M. Fladeland, E. Sterling \& M. Steininger (2003). Remote sensing for biodiversity science and conservation. Trends Ecology and Evolution 18(6): 306-314. https:// doi.org/10.1016/S0169-5347(03)00070-3

United Nations Environment Programme (2020). Emerging zoonotic diseases and links to ecosystem health - UNEP Frontiers 2016 chapter. https://www.unenvironment.org/resources/emergingzoonotic-diseases-and-links-ecosystem-health-unep-frontiers2016-chapter. Electronic version accessed 15 October 2020.

United Nations Environment Programme - Convention on Biological Diversity (2010). The Strategic Plan for Biodiversity 2011-2020 and the Aichi Biodiversity Targets. https://www.cbd.int/sp/. Electronic version accessed 13 August 2020.

University of Copenhagen (2012). Biodiversity crisis is worse than climate change, experts say. ScienceDaily. www.sciencedaily.com/ releases/2012/01/120120010357.htm. Downloaded on 7 October 2020.

Wood, C.L., K.D. Lafferty, G. DeLeo, H.S. Young, P.J. Hudson \& A.M. Kuris (2014). Does biodiversity protect humans against infectious disease? Ecology: Ecological Society of America 95(4): 817-832. https://doi.org/10.1890/13-1041.1

Yahi, N., E. Vela, S. Benhouhou, G. De Belair \& R. Gharzouli (2012). Identifying important plants areas (key biodiversity areas for plants) in northern Algeria. Journal of Threatened Taxa 4(8): 2753-2765. https://doi.org/10.11609/JoTT.o2998.2753-65 
Appendix 1. Conservation priority ranking of the 101 terrestrial key biodiversity areas based on the annual rate of forest cover loss.

\begin{tabular}{|c|c|c|c|c|c|c|c|c|c|c|}
\hline Region & $\begin{array}{l}\text { Terrestrial Key Biodiversity } \\
\text { Areas }\end{array}$ & $\begin{array}{l}\text { Area of } \\
\text { KBA* }\end{array}$ & $\begin{array}{l}\text { Forest } \\
\text { cover in } \\
2000^{*}\end{array}$ & $\begin{array}{c}\text { \% Forest } \\
\text { cover in } \\
2000\end{array}$ & $\begin{array}{c}\text { Remaining } \\
\text { forest } \\
\text { cover in } \\
\text { 2019* }\end{array}$ & $\begin{array}{c}\text { \% forest } \\
\text { cover in } \\
2019\end{array}$ & $\begin{array}{l}\text { Forest } \\
\text { cover } \\
\text { loss* }\end{array}$ & $\begin{array}{l}\text { \% Forest } \\
\text { cover loss }\end{array}$ & $\begin{array}{c}\text { Annual } \\
\text { rate of } \\
\text { forest loss } \\
\text { (ha/year) }\end{array}$ & $\begin{array}{l}\text { Priority } \\
\text { ranking }\end{array}$ \\
\hline$X I I I, X I$ & Bislig & 154.12 & 149.85 & 97 & 111.26 & 72 & -38.59 & -25.75 & -2031.00 & 1 \\
\hline IV-B & Mount Mantalingahan & 146.00 & 140.42 & 96 & 116.35 & 80 & -24.07 & -17.14 & -1266.94 & 2 \\
\hline VIII & Samar Island Natural Park & 333.00 & 330.24 & 99 & 316.20 & 95 & -14.04 & -4.25 & -738.82 & 3 \\
\hline CAR, II, I & Apayao Lowland Forest & 177.37 & 171.43 & 97 & 159.04 & 90 & -12.38 & -7.22 & -651.84 & 4 \\
\hline XIII & Mount Diwata Range & 93.80 & 92.08 & 98 & 81.94 & 87 & -10.15 & -11.02 & -534.04 & 5 \\
\hline $\mathrm{XI}$ & $\begin{array}{l}\text { Mount Agtuuganon and } \\
\text { Mount Pasian }\end{array}$ & 85.50 & 84.92 & 99 & 74.93 & 88 & -9.99 & -11.76 & -525.78 & 6 \\
\hline XIII & Mount Hilong-hilong & 240.24 & 237.66 & 99 & 227.81 & 95 & -9.84 & -4.14 & -518.04 & 7 \\
\hline II & $\begin{array}{l}\text { Quirino Protected } \\
\text { Landscape }\end{array}$ & 164.54 & 149.48 & 91 & 139.87 & 85 & -9.61 & -6.43 & -505.82 & 8 \\
\hline IV-B & San Vicente-Roxas Forests & 81.16 & 77.11 & 95 & 67.88 & 84 & -9.22 & -11.96 & -485.34 & 9 \\
\hline IV-B & $\begin{array}{l}\text { Victoria and Anepahan } \\
\text { Ranges }\end{array}$ & 164.79 & 163.46 & 99 & 154.72 & 94 & -8.74 & -5.35 & -460.14 & 10 \\
\hline XIII, $X$ & \begin{tabular}{|l|} 
Mount Kaluayan-Mount \\
Kinabalian Complex
\end{tabular} & 180.98 & 180.99 & 100 & 172.26 & 95 & -8.73 & -4.82 & -459.62 & 11 \\
\hline $\mathrm{XI}$ & $\begin{array}{l}\text { Mount Kampalili-Puting } \\
\text { Bato }\end{array}$ & 169.91 & 166.94 & 98 & 158.89 & 94 & -8.04 & -4.82 & -423.23 & 12 \\
\hline BARMM, XII & $\begin{array}{l}\text { Mount Piagayungan and } \\
\text { Butig Mountains }\end{array}$ & 154.34 & 148.39 & 96 & 140.73 & 91 & -7.66 & -5.16 & -403.09 & 13 \\
\hline IV-B & Cleopatras Needle & 104.73 & 102.30 & 98 & 95.76 & 91 & -6.55 & -6.40 & -344.64 & 14 \\
\hline IX & Mount Sugarloaf & 34.42 & 32.73 & 95 & 26.43 & 77 & -6.30 & -19.24 & -331.44 & 15 \\
\hline $\mathrm{XI}, \mathrm{XII}$ & Mount Latian complex & 95.08 & 87.45 & 92 & 82.40 & 87 & -5.04 & -5.77 & -265.45 & 16 \\
\hline IX & Lituban Quipit Watershed & 33.29 & 32.64 & 98 & 27.75 & 83 & -4.89 & -14.98 & -257.23 & 17 \\
\hline XIII & $\begin{array}{l}\text { Agusan Marsh Wildlife } \\
\text { Sanctuary }\end{array}$ & 54.77 & 49.20 & 90 & 44.94 & 82 & -4.26 & -8.66 & -224.33 & 18 \\
\hline XII & Mount Busa-Kiamba & 114.14 & 106.07 & 93 & 102.38 & 90 & -3.68 & -3.47 & -193.74 & 19 \\
\hline VI, VII & Southwestern Negros & 196.44 & 83.91 & 43 & 80.46 & 41 & -3.45 & -4.11 & -181.36 & 20 \\
\hline III, I & Zambales mountains & 139.68 & 118.49 & 85 & 115.05 & 82 & -3.44 & -2.91 & -181.19 & 21 \\
\hline IV-A, III & $\begin{array}{l}\text { Mounts Irid-Angilo and } \\
\text { Binuang }\end{array}$ & 115.21 & 114.08 & 99 & 110.71 & 96 & -3.37 & -2.95 & -177.15 & 22 \\
\hline$X I, X I I$ & Mount Apo & 99.08 & 85.68 & 86 & 82.48 & 83 & -3.21 & -3.74 & -168.80 & 23 \\
\hline$x$ & Mount Tago Range & 83.42 & 68.33 & 82 & 65.22 & 78 & -3.10 & -4.54 & -163.34 & 24 \\
\hline X, BARMM & Munai/Tambo & 69.84 & 65.39 & 94 & 62.62 & 90 & -2.77 & -4.24 & -145.95 & 25 \\
\hline VIII & Anonang-Lobi Range & 58.05 & 56.98 & 98 & 54.34 & 94 & -2.63 & -4.62 & -138.51 & 26 \\
\hline II, III & $\begin{array}{l}\text { Casecnan Protected } \\
\text { Landscape }\end{array}$ & 90.72 & 82.07 & 90 & 79.96 & 88 & -2.11 & -2.57 & -111.05 & 27 \\
\hline IV-B & Puerto Galera & 37.31 & 32.33 & 87 & 30.54 & 82 & -1.79 & -5.54 & -94.29 & 28 \\
\hline XII, BARMM & Mount Daguma & 32.36 & 31.02 & 96 & 29.36 & 91 & -1.65 & -5.33 & -87.09 & 29 \\
\hline IV-A & Polillo Islands & 20.28 & 19.95 & 98 & 18.35 & 91 & -1.60 & -8.01 & -84.11 & 30 \\
\hline IV-B & Iglit-Baco Mountains & 56.30 & 47.19 & 84 & 45.61 & 81 & -1.58 & -3.35 & -83.20 & 31 \\
\hline IV-B & Mount Calavite & 18.15 & 13.50 & 74 & 11.94 & 66 & -1.55 & -11.49 & -81.61 & 32 \\
\hline IV-B & Malpalon & 14.09 & 11.86 & 84 & 10.32 & 73 & -1.54 & -13.01 & -81.23 & 33 \\
\hline BARMM & Tawi-tawi Island & 5.85 & 5.53 & 94 & 3.99 & 68 & -1.54 & -27.88 & -81.11 & 34 \\
\hline IX & $\begin{array}{l}\text { Mount Dapiak-Mount } \\
\text { Paraya }\end{array}$ & 14.67 & 13.57 & 92 & 12.06 & 82 & -1.51 & -11.11 & -79.35 & 35 \\
\hline BARMM, XII & Liguasan marsh & 39.42 & 18.10 & 46 & 16.65 & 42 & -1.45 & -8.01 & -76.35 & 36 \\
\hline III & $\begin{array}{l}\text { Aurora Memorial National } \\
\text { Park }\end{array}$ & 47.15 & 42.34 & 90 & 40.91 & 87 & -1.42 & -3.36 & -74.83 & 37 \\
\hline VI & Central Panay mountains & 105.58 & 94.56 & 90 & 93.27 & 88 & -1.29 & -1.36 & -67.67 & 38 \\
\hline
\end{tabular}




\begin{tabular}{|c|c|c|c|c|c|c|c|c|c|c|}
\hline Region & $\begin{array}{l}\text { Terrestrial Key Biodiversity } \\
\text { Areas }\end{array}$ & $\begin{array}{l}\text { Area of } \\
\text { KBA* }\end{array}$ & $\begin{array}{l}\text { Forest } \\
\text { cover in } \\
2000^{*}\end{array}$ & $\begin{array}{c}\text { \% Forest } \\
\text { cover in } \\
2000\end{array}$ & $\begin{array}{c}\text { Remaining } \\
\text { forest } \\
\text { cover in } \\
2019^{*} \\
\end{array}$ & $\begin{array}{l}\text { \% forest } \\
\text { cover in } \\
2019\end{array}$ & $\begin{array}{l}\text { Forest } \\
\text { cover } \\
\text { loss* }\end{array}$ & $\begin{array}{l}\% \text { Forest } \\
\text { cover loss }\end{array}$ & $\begin{array}{c}\text { Annual } \\
\text { rate of } \\
\text { forest loss } \\
\text { (ha/year) }\end{array}$ & $\begin{array}{l}\text { Priority } \\
\text { ranking }\end{array}$ \\
\hline III, II & $\begin{array}{l}\text { North Central Sierra Madre } \\
\text { Mountains }\end{array}$ & 87.48 & 86.21 & 99 & 85.01 & 97 & -1.20 & -1.39 & -62.92 & 39 \\
\hline $\mathrm{VI}$ & $\begin{array}{l}\text { Mount Silay and Mount } \\
\text { Mandalagan (Northern } \\
\text { Negros) }\end{array}$ & 68.88 & 45.21 & 66 & 44.06 & 64 & -1.16 & -2.56 & -60.85 & 40 \\
\hline IV-B & Lake Manguao & 6.45 & 5.32 & 82 & 4.18 & 65 & -1.14 & -21.46 & -60.05 & 41 \\
\hline VIII & Mount Nacolod & 33.49 & 32.80 & 98 & 31.67 & 95 & -1.14 & -3.47 & -59.88 & 42 \\
\hline IV-B & Mount Halcon & 50.95 & 44.43 & 87 & 43.30 & 85 & -1.13 & -2.55 & -59.64 & 43 \\
\hline$X I$ & $\begin{array}{l}\text { Mount Hamiguitan } \\
\text { (Tumadgo peak) }\end{array}$ & 31.88 & 31.27 & 98 & 30.19 & 95 & -1.08 & -3.45 & -56.69 & 44 \\
\hline IV-B & Busuanga Island & 16.33 & 15.94 & 98 & 14.90 & 91 & -1.04 & -6.55 & -54.99 & 45 \\
\hline $\mathrm{X}, \mathrm{IX}$ & Mount Malindang & 40.69 & 37.11 & 91 & 36.22 & 89 & -0.90 & -2.41 & -47.16 & 46 \\
\hline IV-A & $\begin{array}{l}\text { Taal Volcano Protected } \\
\text { Landscape }\end{array}$ & 65.93 & 31.98 & 49 & 31.10 & 47 & -0.88 & -2.76 & -46.48 & 47 \\
\hline IV-B & Mount Hitding & 17.77 & 16.56 & 93 & 15.70 & 88 & -0.87 & -5.24 & -45.67 & 48 \\
\hline IV-B & Mount Siburan & 11.57 & 9.53 & 82 & 8.68 & 75 & -0.86 & -9.00 & -45.18 & 49 \\
\hline XIII & $\begin{array}{l}\text { Mount Kambinlio and } \\
\text { Mount Redondo }\end{array}$ & 28.52 & 27.07 & 95 & 26.27 & 92 & -0.80 & -2.95 & -41.97 & 50 \\
\hline VII & Mount Capayas & 13.61 & 10.44 & 77 & 9.66 & 71 & -0.78 & -7.48 & -41.07 & 51 \\
\hline VII, VI & Ban-ban & 28.54 & 16.13 & 57 & 15.39 & 54 & -0.74 & -4.60 & -39.07 & 52 \\
\hline VII & $\begin{array}{l}\text { Central Cebu Protected } \\
\text { Landscape }\end{array}$ & 29.22 & 19.52 & 67 & 18.79 & 64 & -0.73 & -3.73 & -38.27 & 53 \\
\hline VII & Cuernos de Negros & 23.56 & 21.34 & 91 & 20.63 & 88 & -0.71 & -3.33 & -37.41 & 54 \\
\hline XII & Mount Matutum & 18.89 & 11.82 & 63 & 11.13 & 59 & -0.69 & -5.84 & -36.35 & 55 \\
\hline III & Mount Dingalan & 46.89 & 45.93 & 98 & 45.25 & 97 & -0.67 & -1.47 & -35.49 & 56 \\
\hline CAR & \begin{tabular}{|l} 
Balbalasang-Balbalan \\
National Park \\
\end{tabular} & 81.54 & 77.79 & 95 & 77.12 & 95 & -0.67 & -0.86 & -35.26 & 57 \\
\hline V & $\begin{array}{l}\text { Catanduanes Watershed } \\
\text { Forest Reserve }\end{array}$ & 28.24 & 28.00 & 99 & 27.33 & 97 & -0.67 & -2.39 & -35.18 & 58 \\
\hline IV-B & Balogo watershed & 10.50 & 9.38 & 89 & 8.74 & 83 & -0.63 & -6.76 & -33.35 & 59 \\
\hline III, NCR & Manila Bay & 96.34 & 24.20 & 25 & 23.59 & 24 & -0.60 & -2.50 & -31.81 & 60 \\
\hline v & Bacon-Manito & 12.75 & 12.45 & 98 & 11.93 & 94 & -0.53 & -4.25 & -27.84 & 61 \\
\hline v & Caramoan peninsula & 18.85 & 18.72 & 99 & 18.23 & 97 & -0.49 & -2.64 & -26.05 & 62 \\
\hline III & Angat watershed & 15.41 & 13.29 & 86 & 12.82 & 83 & -0.47 & -3.52 & -24.60 & 63 \\
\hline BARMM & Basilan Natural Biotic Area & 4.48 & 4.45 & 99 & 4.02 & 90 & -0.43 & -9.58 & -22.44 & 64 \\
\hline$x$ & \begin{tabular}{|l|} 
Mount Kalatungan \\
Mountains Ranges Natural \\
Park
\end{tabular} & 35.77 & 31.90 & 89 & 31.48 & 88 & -0.42 & -1.31 & -22.01 & 65 \\
\hline CAR, II & Mount Pulag National Park & 13.29 & 12.56 & 94 & 12.18 & 92 & -0.38 & -3.03 & -20.04 & 66 \\
\hline IX & Pasonanca Natural Park & 10.42 & 10.03 & 96 & 9.66 & 93 & -0.36 & -3.63 & -19.18 & 67 \\
\hline$x$ & Mount Balatukan & 35.25 & 29.24 & 83 & 28.90 & 82 & -0.34 & -1.16 & -17.78 & 68 \\
\hline IV-B & Romblon Island & 8.19 & 7.10 & 87 & 6.77 & 83 & -0.32 & -4.58 & -17.10 & 69 \\
\hline IV-A & $\begin{array}{l}\text { University of the Philippines } \\
\text { Land Grants (Pakil and Real) }\end{array}$ & 11.12 & 10.77 & 97 & 10.47 & 94 & -0.30 & -2.80 & -15.87 & 70 \\
\hline III & \begin{tabular}{|l} 
Bataan Natural Park and \\
Subic Bay Forest Reserve
\end{tabular} & 25.25 & 23.47 & 93 & 23.17 & 92 & -0.29 & -1.24 & -15.36 & 71 \\
\hline IV-B & Mount Hinunduang & 8.22 & 8.08 & 98 & 7.79 & 95 & -0.29 & -3.59 & -15.27 & 72 \\
\hline III & Mariveles mountains & 12.10 & 11.23 & 93 & 10.94 & 90 & -0.29 & -2.57 & -15.17 & 73 \\
\hline VIII & Biliran and Maripipi Island & 12.76 & 12.36 & 97 & 12.07 & 95 & -0.28 & -2.29 & -14.92 & 74 \\
\hline VI, VII & $\begin{array}{l}\text { Mount Kanla-on Natural } \\
\text { Park }\end{array}$ & 24.78 & 16.22 & 65 & 15.94 & 64 & -0.28 & -1.74 & -14.86 & 75 \\
\hline V, IV-A & Mount Labo & 13.78 & 13.66 & 99 & 13.38 & 97 & -0.28 & -2.02 & -14.52 & 76 \\
\hline
\end{tabular}




\begin{tabular}{|c|c|c|c|c|c|c|c|c|c|c|}
\hline Region & $\begin{array}{l}\text { Terrestrial Key Biodiversity } \\
\text { Areas }\end{array}$ & $\begin{array}{c}\text { Area of } \\
\text { KBA* }\end{array}$ & $\begin{array}{l}\text { Forest } \\
\text { cover in } \\
2000^{*}\end{array}$ & $\begin{array}{c}\% \text { Forest } \\
\text { cover in } \\
2000\end{array}$ & $\begin{array}{c}\text { Remaining } \\
\text { forest } \\
\text { cover in } \\
\text { 2019* }\end{array}$ & $\begin{array}{c}\% \text { forest } \\
\text { cover in } \\
2019\end{array}$ & $\begin{array}{l}\text { Forest } \\
\text { cover } \\
\text { loss* }\end{array}$ & $\begin{array}{l}\% \text { Forest } \\
\text { cover loss }\end{array}$ & $\begin{array}{c}\text { Annual } \\
\text { rate of } \\
\text { forest loss } \\
\text { (ha/year) }\end{array}$ & $\begin{array}{l}\text { Priority } \\
\text { ranking }\end{array}$ \\
\hline VI & $\begin{array}{l}\text { North west Panay peninsula } \\
\text { (Pandan) }\end{array}$ & 12.06 & 11.70 & 97 & 11.44 & 95 & -0.26 & -2.18 & -13.44 & 77 \\
\hline IV-B & $\begin{array}{l}\text { Marinduque Wildlife } \\
\text { Sanctuary (Central) }\end{array}$ & 8.92 & 8.29 & 93 & 8.04 & 90 & -0.25 & -2.99 & -13.06 & 78 \\
\hline VII & Nug-as and Mount Lantoy & 10.46 & 6.67 & 64 & 6.47 & 62 & -0.20 & -2.96 & -10.39 & 79 \\
\hline VII & $\begin{array}{l}\text { Rajah Sikatuna Protected } \\
\text { Landscape }\end{array}$ & 12.40 & 11.22 & 91 & 11.03 & 89 & -0.20 & -1.74 & -10.28 & 80 \\
\hline IV-A & Mount Makiling & 6.23 & 5.92 & 95 & 5.76 & 93 & -0.16 & -2.71 & -8.46 & 81 \\
\hline I & $\begin{array}{l}\text { Kalbario-Patapat National } \\
\text { Park }\end{array}$ & 8.97 & 8.69 & 97 & 8.53 & 95 & -0.16 & -1.79 & -8.17 & 82 \\
\hline v & Mount Isarog National Park & 10.00 & 9.60 & 96 & 9.44 & 94 & -0.16 & -1.62 & -8.16 & 83 \\
\hline IV-A & Pagbilao and Tayabas Bay & 2.69 & 1.79 & 66 & 1.64 & 61 & -0.15 & -8.12 & -7.63 & 84 \\
\hline IV-B & $\begin{array}{l}\text { Mount Guiting-guiting } \\
\text { Natural Park }\end{array}$ & 15.34 & 15.22 & 99 & 15.07 & 98 & -0.15 & -0.99 & -7.93 & 85 \\
\hline V & $\begin{array}{l}\text { Bulusan Volcano Natural } \\
\text { Park }\end{array}$ & 3.72 & 3.42 & 92 & 3.30 & 89 & -0.12 & -3.45 & -6.21 & 86 \\
\hline II & Buguey wetlands & 10.87 & 2.34 & 22 & 2.26 & 21 & -0.08 & -3.52 & -4.34 & 87 \\
\hline BARMM & Mount Dajo National Park & 3.30 & 3.04 & 92 & 2.97 & 90 & -0.07 & -2.29 & -3.67 & 88 \\
\hline$x$ & Mount Kitanglad & 31.02 & 29.55 & 95 & 29.48 & 95 & -0.07 & -0.24 & -3.73 & 89 \\
\hline BARMM & Lake Lanao & 36.35 & 3.14 & 9 & 3.08 & 8 & -0.06 & -2.01 & -3.33 & 90 \\
\hline$X I I, X I$ & Mount Sinaka & 1.75 & 1.54 & 88 & 1.48 & 85 & -0.05 & -3.46 & -2.80 & 91 \\
\hline v & Mount Kulasi & 3.05 & 3.03 & 99 & 2.97 & 98 & -0.05 & -1.81 & -2.89 & 92 \\
\hline IV-A & Quezon National Park & 1.98 & 1.95 & 98 & 1.90 & 96 & -0.05 & -2.39 & -2.45 & 93 \\
\hline VII & $\begin{array}{l}\text { Mount Kangbulagsing and } \\
\text { Mount Lanaya }\end{array}$ & 2.62 & 1.72 & 66 & 1.68 & 64 & -0.04 & -2.28 & -2.07 & 94 \\
\hline IV-A & $\begin{array}{l}\text { Mount Palay-Palay-Mataas } \\
\text { Na Gulod National Park }\end{array}$ & 1.83 & 1.77 & 97 & 1.74 & 95 & -0.03 & -1.55 & -1.44 & 95 \\
\hline III & Candaba swamp & 1.91 & 0.55 & 29 & 0.53 & 28 & -0.03 & -4.76 & -1.39 & 96 \\
\hline IX & Mount Timolan & 1.92 & 1.84 & 96 & 1.80 & 94 & -0.03 & -1.87 & -1.81 & 97 \\
\hline IV-A & $\begin{array}{l}\text { Mounts. Banahaw-San } \\
\text { Cristobal Protected } \\
\text { Landscape }\end{array}$ & 11.33 & 10.68 & 94 & 10.65 & 94 & -0.03 & -0.27 & -1.54 & 98 \\
\hline VII & Mount Bandila-an & 1.78 & 1.60 & 90 & 1.57 & 88 & -0.03 & -1.65 & -1.39 & 99 \\
\hline$x$ & $\begin{array}{l}\text { Timpoong and Hibok-hibok } \\
\text { Natural Monument }\end{array}$ & 3.73 & 3.45 & 93 & 3.44 & 92 & -0.01 & -0.31 & -0.56 & 100 \\
\hline \multirow[t]{3}{*}{ ॥ } & Malasi Lake & 0.16 & 0.01 & 3 & 0.00 & 2 & 0.00 & -52.57 & -0.15 & 101 \\
\hline & Grand Total & 5129.8 & 4540.39 & & 4270.33 & & -270.06 & & -14213.79 & \\
\hline & Average & & & 86 & & 81 & & -6 & & \\
\hline
\end{tabular}

* Thousand ha 
Dr. John Noyes, Natural History Museum, London, UK

Dr. Albert G. Orr, Griffith University, Nathan, Australia

Dr. Sameer Padhye, Katholieke Universiteit Leuven, Belgium

Dr. Nancy van der Poorten, Toronto, Canada

Dr. Kareen Schnabel, NIWA, Wellington, New Zealand

Dr. R.M. Sharma, (Retd.) Scientist, Zoological Survey of India, Pune, India

Dr. Manju Siliwal, WILD, Coimbatore, Tamil Nadu, India

Dr. G.P. Sinha, Botanical Survey of India, Allahabad, India

Dr. K.A. Subramanian, Zoological Survey of India, New Alipore, Kolkata, India

Dr. P.M. Sureshan, Zoological Survey of India, Kozhikode, Kerala, India

Dr. R. Varatharajan, Manipur University, Imphal, Manipur, India

Dr. Eduard Vives, Museu de Ciències Naturals de Barcelona, Terrassa, Spain

Dr. James Young, Hong Kong Lepidopterists' Society, Hong Kong

Dr. R. Sundararaj, Institute of Wood Science \& Technology, Bengaluru, India

Dr. M. Nithyanandan, Environmental Department, La Ala Al Kuwait Real Estate. Co. K.S.C.,

Kuwait

Dr. Himender Bharti, Punjabi University, Punjab, India

Mr. Purnendu Roy, London, UK

Dr. Saito Motoki, The Butterfly Society of Japan, Tokyo, Japan

Dr. Sanjay Sondhi, TITLI TRUST, Kalpavriksh, Dehradun, India

Dr. Nguyen Thi Phuong Lien, Vietnam Academy of Science and Technology, Hanoi, Vietnam

Dr. Nitin Kulkarni, Tropical Research Institute, Jabalpur, India

Dr. Robin Wen Jiang Ngiam, National Parks Board, Singapore

Dr. Lional Monod, Natural History Museum of Geneva, Genève, Switzerland.

Dr. Asheesh Shivam, Nehru Gram Bharti University, Allahabad, India

Dr. Rosana Moreira da Rocha, Universidade Federal do Paraná, Curitiba, Brasi

Dr. Kurt R. Arnold, North Dakota State University, Saxony, Germany

Dr. James M. Carpenter, American Museum of Natural History, New York, USA

Dr. David M. Claborn, Missouri State University, Springfield, USA

Dr. Kareen Schnabel, Marine Biologist, Wellington, New Zealand

Dr. Amazonas Chagas Júnior, Universidade Federal de Mato Grosso, Cuiabá, Brasil

Mr. Monsoon Jyoti Gogoi, Assam University, Silchar, Assam, India

Dr. Heo Chong Chin, Universiti Teknologi MARA (UiTM), Selangor, Malaysia

Dr. R.J. Shiel, University of Adelaide, SA 5005, Australia

Dr. Siddharth Kulkarni, The George Washington University, Washington, USA

Dr. Priyadarsanan Dharma Rajan, ATREE, Bengaluru, India

Dr. Phil Alderslade, CSIRO Marine And Atmospheric Research, Hobart, Australia

Dr. John E.N. Veron, Coral Reef Research, Townsville, Australia

Dr. Daniel Whitmore, State Museum of Natural History Stuttgart, Rosenstein, Germany.

Dr. Yu-Feng Hsu, National Taiwan Normal University, Taipei City, Taiwan

Dr. Keith V. Wolfe, Antioch, California, USA

Dr. Siddharth Kulkarni, The Hormiga Lab, The George Washington University, Washington,

D.C., USA

Dr. Tomas Ditrich, Faculty of Education, University of South Bohemia in Ceske

Budejovice, Czech Republic

Dr. Mihaly Foldvari, Natural History Museum, University of Oslo, Norway

Dr. V.P. Uniyal, Wildlife Institute of India, Dehradun, Uttarakhand 248001, India

Dr. John T.D. Caleb, Zoological Survey of India, Kolkata, West Bengal, India

Dr. Priyadarsanan Dharma Rajan, Ashoka Trust for Research in Ecology and the Environment

(ATREE), Royal Enclave, Bangalore, Karnataka, India

\section{Fishes}

Dr. Neelesh Dahanukar, IISER, Pune, Maharashtra, India

Dr. Topiltzin Contreras MacBeath, Universidad Autónoma del estado de Morelos, México

Dr. Heok Hee Ng, National University of Singapore, Science Drive, Singapore

Dr. Rajeev Raghavan, St. Albert's College, Kochi, Kerala, India

Dr. Robert D. Sluka, Chiltern Gateway Project, A Rocha UK, Southall, Middlesex, UK

Dr. E. Vivekanandan, Central Marine Fisheries Research Institute, Chennai, India

Dr. Davor Zanella, University of Zagreb, Zagreb, Croatia

Dr. A. Biju Kumar, University of Kerala, Thiruvananthapuram, Kerala, India

Dr. Akhilesh K.V., ICAR-Central Marine Fisheries Research Institute, Mumbai Research

Centre, Mumbai, Maharashtra, India

Dr. J.A. Johnson, Wildlife Institute of India, Dehradun, Uttarakhand, India

Amphibians

Dr. Sushil K. Dutta, Indian Institute of Science, Bengaluru, Karnataka, India

Dr. Annemarie Ohler, Muséum national d'Histoire naturelle, Paris, France

\section{Reptiles}

Dr. Gernot Vogel, Heidelberg, Germany

Dr. Raju Vyas, Vadodara, Gujarat, India

Dr. Pritpal S. Soorae, Environment Agency, Abu Dubai, UAE.

Prof. Dr. Wayne J. Fuller, Near East University, Mersin, Turkey

Prof. Chandrashekher U. Rivonker, Goa University, Taleigao Plateau, Goa. India

Dr. S.R. Ganesh, Chennai Snake Park, Chennai, Tamil Nadu, India

Dr. Himansu Sekhar Das, Terrestrial \& Marine Biodiversity, Abu Dhabi, UAE
Birds

Dr. Hem Sagar Baral, Charles Sturt University, NSW Australia

Dr. Chris Bowden, Royal Society for the Protection of Birds, Sandy, UK

Dr. Priya Davidar, Pondicherry University, Kalapet, Puducherry, India

Dr. J.W. Duckworth, IUCN SSC, Bath, UK

Dr. Rajah Jayapal, SACON, Coimbatore, Tamil Nadu, India

Dr. Rajiv S. Kalsi, M.L.N. College, Yamuna Nagar, Haryana, India

Dr. V. Santharam, Rishi Valley Education Centre, Chittoor Dt., Andhra Pradesh, India

Dr. S. Balachandran, Bombay Natural History Society, Mumbai, India

Mr. J. Praveen, Bengaluru, India

Dr. C. Srinivasulu, Osmania University, Hyderabad, India

Dr. K.S. Gopi Sundar, International Crane Foundation, Baraboo, USA

Dr. Gombobaatar Sundev, Professor of Ornithology, Ulaanbaatar, Mongolia

Prof. Reuven Yosef, International Birding \& Research Centre, Eilat, Israel

Dr. Taej Mundkur, Wetlands International, Wageningen, The Netherlands

Dr. Carol Inskipp, Bishop Auckland Co., Durham, UK

Dr. Tim Inskipp, Bishop Auckland Co, Durham, UK

Dr. V. Gokula, National College, Tiruchirappalli, Tamil Nadu, India

Dr. Arkady Lelej, Russian Academy of Sciences, Vladivostok, Russia

Dr. Simon Dowell, Science Director, Chester Zoo, UK

Dr. Mário Gabriel Santiago dos Santos, Universidade de Trás-os-Montes e Alto Douro,

Quinta de Prados, Vila Real, Portugal

Dr. Grant Connette, Smithsonian Institution, Royal, VA, USA

Dr. M. Zafar-ul Islam, Prince Saud Al Faisal Wildlife Research Center, Taif, Saudi Arabia

Mammals

Dr. Giovanni Amori, CNR - Institute of Ecosystem Studies, Rome, Italy

Dr. Anwaruddin Chowdhury, Guwahati, India

Dr. David Mallon, Zoological Society of London, UK

Dr. Shomita Mukherjee, SACON, Coimbatore, Tamil Nadu, India

Dr. Angie Appel, Wild Cat Network, Germany

Dr. P.O. Nameer, Kerala Agricultural University, Thrissur, Kerala, India

Dr. Ian Redmond, UNEP Convention on Migratory Species, Lansdown, UK

Dr. Heidi S. Riddle, Riddle's Elephant and Wildlife Sanctuary, Arkansas, USA

Dr. Karin Schwartz, George Mason University, Fairfax, Virginia.

Dr. Lala A.K. Singh, Bhubaneswar, Orissa, India

Dr. Mewa Singh, Mysore University, Mysore, India

Dr. Paul Racey, University of Exeter, Devon, UK

Dr. Honnavalli N. Kumara, SACON, Anaikatty P.O., Coimbatore, Tamil Nadu, India

Dr. Nishith Dharaiya, HNG University, Patan, Gujarat, India

Dr. Spartaco Gippoliti, Socio Onorario Società Italiana per la Storia della Fauna "Giuseppe

Altobello", Rome, Italy

Dr. Justus Joshua, Green Future Foundation, Tiruchirapalli, Tamil Nadu, India

Dr. H. Raghuram, The American College, Madurai, Tamil Nadu, India

Dr. Paul Bates, Harison Institute, Kent, UK

Dr. Jim Sanderson, Small Wild Cat Conservation Foundation, Hartford, USA

Dr. Dan Challender, University of Kent, Canterbury, UK

Dr. David Mallon, Manchester Metropolitan University, Derbyshire, UK

Dr. Brian L. Cypher, California State University-Stanislaus, Bakersfield, CA

Dr. S.S. Talmale, Zoological Survey of India, Pune, Maharashtra, India

Prof. Karan Bahadur Shah, Budhanilakantha Municipality, Kathmandu, Nepal

Dr. Susan Cheyne, Borneo Nature Foundation International, Palangkaraja, Indonesia

Dr. Hemanta Kafley, Wildlife Sciences, Tarleton State University, Texas, USA

\section{Other Disciplines}

Dr. Aniruddha Belsare, Columbia MO 65203, USA (Veterinary)

Dr. Mandar S. Paingankar, University of Pune, Pune, Maharashtra, India (Molecular)

Dr. Jack Tordoff, Critical Ecosystem Partnership Fund, Arlington, USA (Communities)

Dr. Ulrike Streicher, University of Oregon, Eugene, USA (Veterinary)

Dr. Hari Balasubramanian, EcoAdvisors, Nova Scotia, Canada (Communities)

Dr. Rayanna Hellem Santos Bezerra, Universidade Federal de Sergipe, São Cristóvão, Brazil

Dr. Jamie R. Wood, Landcare Research, Canterbury, New Zealand

Dr. Wendy Collinson-Jonker, Endangered Wildlife Trust, Gauteng, South Africa

Dr. Rajeshkumar G. Jani, Anand Agricultural University, Anand, Gujarat, India

Dr. O.N. Tiwari, Senior Scientist, ICAR-Indian Agricultural Research Institute (IARI), New

Delhi, India

Dr. L.D. Singla, Guru Angad Dev Veterinary and Animal Sciences University, Ludhiana, India

Dr. Rupika S. Rajakaruna, University of Peradeniya, Peradeniya, Sri Lanka

Dr. Bahar Baviskar, Wild-CER, Nagpur, Maharashtra 440013, India

Reviewers 2018-2020

Due to pausity of space, the list of reviewers for $2018-2020$ is available online.

The opinions expressed by the authors do not reflect the views of the Journal of Threatened Taxa, Wildlife Information Liaison Development Society, Zoo Outreach Organization, or any of the partners. The journal, the publisher, the host, and the partners are not responsible for the accuracy of the political boundaries shown in the maps by the authors.

Journal of Threatened Taxa is indexed/abstracted in Bibliography of Systematic Mycology, Biological Abstracts, BIOSIS Previews, CAB Abstracts, EBSCO, Google Scholar, Index Copernicus, Index Fungorum, JournalSeek, National Academy of Agricultural Sciences, NewJour, OCLC WorldCat, SCOPUS, Stanford University Libraries, Virtual Library of Biology, Zoological Records.

NAAS rating (India) 5.64
Print copies of the Journal are available at cost. Write to:

The Managing Editor, JoTT,

c/o Wildlife Information Liaison Development Society,

No. 12, Thiruvannamalai Nagar, Saravanampatti - Kalapatti Road,

Saravanampatti, Coimbatore, Tamil Nadu 641035, India

ravi@threatenedtaxa.org 


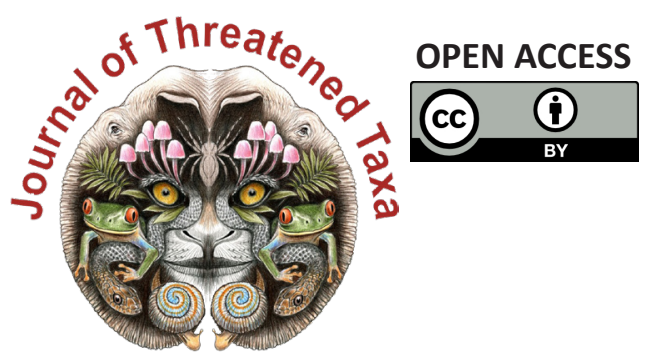

www.threatenedtaxa.org

The Journal of Threatened Taxa (JoTT) is dedicated to building evidence for conservation globally by publishing peer-reviewed articles online every month at a reasonably rapid rate at www.threatenedtaxa.org. All articles published in JoTT are registered under Creative Commons Attribution 4.0 International License unless otherwise mentioned. JoTT allows allows unrestricted use, reproduction, and distribution of articles in any medium by providing adequate credit to the author(s) and the source of publication.

ISSN 0974-7907 (Online) I ISSN $0974-7893$ (Print)

\section{November 2021 | Vol. 13 | No. 13 | Pages: 19887-20142 \\ Date of Publication: 26 November 2021 (Online \& Print) DOI: 10.11609/jott.2021.13.13.19887-20142}

\section{Article}

An inventory of geometrid moths (Lepidoptera: Geometroidea: Geometridae) of KalakadMundanthurai Tiger Reserve, India

- Geetha Iyer, Dieter Stüning \& Sanjay Sondhi, Pp. 19887-19920

\section{Communications}

Roadkills of Lowland Tapir Tapirus terrestris (Mammalia: Perissodactyla: Tapiridae) in one of its last refuges in the Atlantic Forest

- Aureo Banhos, Andressa Gatti, Marcelo Renan de Deus Santos, Leonardo Merçon,

Ilka Westermeyer, Natália Carneiro Ardente, Luis Francisco Oliveira Pereira Gonzaga, Lucas Mendes Barreto, Lucas Damásio, Tomas Lima Rocha, Vitor Roberto Schettino, Renata Valls, Helena Godoy Bergallo, Marcos Vinicius Freitas Silva, Athelson Stefanon Bittencourt, Danielle de Oliveira Moreira \& Ana Carolina Srbek-Araujo, Pp. 19921-19929

Scientific contributions and learning experiences of citizen volunteers with a small cat project in Sanjay Gandhi National Park, Mumbai, India

- Shomita Mukherjee, R. Nandini, P.V. Karunakaran \& Nayan Khanolkar, Pp. 19930-19936

Seasonal food preferences and group activity pattern of Blackbuck Antilope cervicapra (L., 1758) (Mammalia: Cetartiodactyla: Bovidae) in a semi-arid region of western Haryana, India

- Vikram Delu, Dharambir Singh, Sumit Dookia, Priya \& Kiran, Pp. 19937-19947

Studies on the habitats of Grey Francolin Francolinus pondicerianus (J.F. Gmelin, 1789) (Galliformes: Phasianidae) in northern districts of Tamil Nadu, India

- M. Pandian, Pp. 19948-19955

Recovery of vulture population in roosting and scavenging areas of Bastar and Bijapur, Chhattisgarh, India

- Sushil Kumar Dutta, Muntaz Khan, P.R.S. Nagi, Santosh Durgam \& Surabhi Dutta, Pp. 19956-19963

A geographical assessment of Chariganga and Arpara Beel (wetlands) of Nadia, West Bengal as a habitat of wetland birds

- Mehedi Hasan Mandal, Arindam Roy \& Giyasuddin Siddique, Pp. 19964-19975

Phenotypic plasticity in Barilius vagra (Hamilton, 1822) (Teleostei: Danionidae) from two geographically distinct river basins of Indian Himalaya

- Sumit Kumar, Sharali Sharma \& Deepak Singh, Pp. 19976-19984

Taxonomic notes, a new species, and a key to Indian species of the click beetle genus Cryptalaus Ôhira, 1967 (Coleoptera: Elateridae: Agrypninae)

- Harshad Parekar \& Amol Patwardhan, Pp. 19985-19999

Niche overlap of benthic macrofauna in a tropical estuary: diurnal variation

- Mário Herculano de Oliveira, Lidiane Gomes de Lima, Caroline Stefani da Silva Lima, Jéssica de Oliveira Lima Gomes, Franciely Ferreira Paiva, Graciele de Barros, Carlinda Railly Medeiros \& Joseline Molozzi, Pp. 20000-20010

Diversity of aquatic insects and biomonitoring of water quality in the upper Ganga River, a Ramsar site: a preliminary assessment

- Kritish De, Arkojyoti Sarkar, Kritika Singh, Virendra Prasad Uniyal, Jeyaraj Antony Johnson \& Syed Ainul Hussain, Pp. 20011-20018

Patterns of forest cover loss in the terrestrial Key Biodiversity Areas in the Philippines: critical habitat conservation priorities

- Bernard Peter O. Daipan, Pp. 20019-20032

The woody flora of Shettihalli Wildlife Sanctuary, central Western Ghats of Karnataka, India - A checklist

- Kanda Naveen Babu, Kurian Ayushi, Vincy K. Wilson, Narayanan Ayyappan \&

Narayanaswamy Parthasarathy, Pp. 20033-20055

Reproductive biology of Ophiorrhiza caudata C.E.C.Fisch. (Rubiaceae), an endemic and endangered creeping perennial herb of the Western Ghats, India

- Maria Theresa, Appukuttan Kamalabai Sreekala \& Jayalakshmi Mohanlal, Pp. 20056-20065
Short Communications

Successful rescue, medical management, rehabilitation, and translocation of a Red Panda Ailurus fulgens (Mammalia: Carnivora: Ailuridae) in Arunachal Pradesh, India - Jahan Ahmed, Sorang Tadap, Millo Tasser, Koj Rinya, Nekibuddin Ahmed \& Sunil Kyarong, Pp. 20066-20071

A rare photographic record of Eurasian Otter Lutra lutra with a note on its habitat from the Bhagirathi Basin, western Himalaya, India

- Ranjana Pal, Aashna Sharma, Vineet Kumar Dubey, Tapajit Bhattacharya, Jeyaraj Antony Johnson, Kuppusamy Sivakumar \& Sambandam Sathyakumar, Pp. 20072-20077

The first record of Medog Gliding Frog Rhacophorus translineatus Wu, 1977 (Anura: Rhacophoridae) from Chhukha District, Bhutan

- Sonam Lhendup \& Bal Krishna Koirala, Pp. 20078-20083

First record of a freshwater crab, Maydelliathelphusa masoniana (Henderson, 1893) (Decapoda: Brachyura: Gecarcinucidae) from West Bengal, India

- Ram Krishna Das, Pp. 20084-20089

Butterflies of Amrabad Tiger Reserve, Telangana, India

- Deepa Jaiswal, B. Bharath, M. Karuthapandi, Shrikant Jadhav, S. Prabakaran \& S. Rehanuma Sulthana, Pp. 20090-20097

An enumeration of the flowering plants of Kyongnosla Alpine Sanctuary in eastern Sikkim, India

- Sudhansu Sekhar Dash, Subhajit Lahiri \& Ashiho Asoshii Mao, Pp. 20098-20117

A new record of psychrotrophic Paecilomyces formosus (Eurotiales: Ascomycota) from India: morphological and molecular characterization

- Skarma Nonzom \& Geeta Sumbali, Pp. 20118-20123

Notes

Study on incidence and pathology of gastrointestinal parasitic infections in Nilgai Boselaphus tragocamelus in Hisar, Haryana, India

- Maneesh Sharma, B.L. Jangir, D. Lather, G.A. Chandratre, V. Nehra, K.K. Jakhar \& G. Narang, Pp. 20124-20127

An unusual vocalization of Brown Hawk-Owl Ninox scutulata (Raffles, 1822) (Aves:

Strigiformes: Strigidae) recorded from Kerala, India

- Riju P. Nair \& Shine Raj Tholkudiyil, Pp. 20128-20129

New distribution data on the genus Maripanthus Maddison, 2020 (Araneae: Salticidae) from southern India

- A. Asima, John T.D. Caleb, Dhruv A. Prajapati \& G. Prasad, Pp. 20130-20132

On the IUCN status of Boesenbergia albolutea and B. rubrolutea (Zingiberaceae) and typification of $B$. rubrolutea

- K. Aishwarya \& M. Sabu, Pp. 20133-20135

New records of mass seeding Cephalostachyum latifolium Munro (Poaceae) along the midelevation broadleaved forest of Sarpang district, Bhutan

- Jigme Tenzin, Sangay Nidup \& Dago Dorji, Pp. 20136-20139

Response

If habitat heterogeneity is effective for conservation of butterflies in urban landscapes of Delhi, India?' Unethical publication based on data manipulation

- Sanjay Keshari Das \& Rita Singh, Pp. 20140-20142

Publisher \& Host
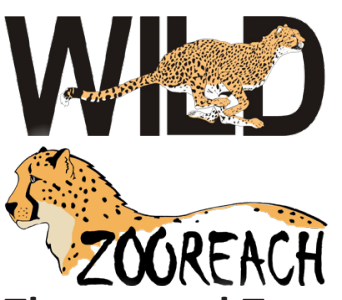

Threatened Taxa 